HEDL-TME--74-34

DE82 020089

SODIUM-FIRE CONTROL

BY SPACE ISOLATION

WITH NITROGEN FLOODING:

FFTF PROOF TEST F2

by

R. K. Hilliard and L. D. Muhlestein June, 1974

This report was prepared as an account of work

sponsored by the United States Government. Neither

the United States nor the United States Atomic Energy

Commission, nor any of their employees, nor any of

their contractors, subcontractors, or their employees,

makes any warranty, express or implied. or ssumes any

legal liability or responsibility for the accuracy, com-

pleteness or usefulness of any information,

product or process disclosed, or represents that its use

would not infringe privately owned rights.

This document is

PUBLICLY RELEASABLE

B Steale

Authorizing Official

Date:

$5-23-07$

- HANFORD ENGINEERING DEVELOPMENT LABORATORY

P.O. Box 1970 Richland, WA 99352

Operated by Westinghouse Hanford Company

A Subsidiary of Westinghouse Electric Corporation

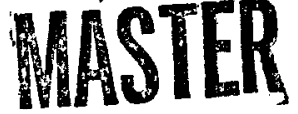

Prepared for the U.S. Atomic Energy Commission Division of Reactor Research and Development under Contract No. AT(45-1)-2170

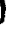




\section{DISCLAIMER}

This report was prepared as an account of work sponsored by an agency of the United States Government. Neither the United States Government nor any agency Thereof, nor any of their employees, makes any warranty, express or implied, or assumes any legal liability or responsibility for the accuracy, completeness, or usefulness of any information, apparatus, product, or process disclosed, or represents that its use would not infringe privately owned rights. Reference herein to any specific commercial product, process, or service by trade name, trademark, manufacturer, or otherwise does not necessarily constitute or imply its endorsement, recommendation, or favoring by the United States Government or any agency thereof. The views and opinions of authors expressed herein do not necessarily state or reflect those of the United States Government or any agency thereof. 


\section{DISCLAIMER}

Portions of this document may be illegible in electronic image products. Images are produced from the best available original document. 



\title{
SODIUM FIRE CONTROL BY SPACE ISOLATION WITH NITROGEN FLOODING - FFTF PROOF TEST F2
}

\begin{abstract}
Sodium fire protection by space isolation with nitrogen flooding was evaluated by performing a large-scale sodium fire test within a mockup of an FETF secondary sodium system pipeway. The fuzz scale (3350 $\left.\mathrm{ft}^{3}\right)$ mockup was initially filled with air and its leak tightness set to correspond to that expected in an actual FLTF pipeway. The basis for speoifying the rate of nitrogen flood gas is discussed and the experimental verification provided. Nitrogen flooding was activated 15 minutes after the spill of $770 \mathrm{lb}$ of $1100^{\circ} \mathrm{F}$ sodium into a 32 $\mathrm{ft}^{2}$ steel pan. The nitrogen flow was controlled momally at a constont rate of $60 \mathrm{ft}^{3} / \mathrm{min}$ (STP) untit the pool temperature had decreased to $370^{\circ} \mathrm{F}$. After cooldown, $87 \%$ of the spilled sodium remained $i n$ the unreacted form, demonstrating that sodium fires can be effectively controlled by the method of space isolation with nitrogen flooding.
\end{abstract}


$\checkmark$<smiles>C1CCC1</smiles> 
CONTENTS

Page

I - INTRODUCTION

11. SUMMARY AND CONCLUSIONS 2

III - TEST CONDITIONS

A. EXPERIMENTAL PROCEDURE 4

B. EXPERIMENTAL EQUIPMENT

1. Description of the LSFF 5

2. FFTF Pipeway Mockup : 8

3. Sodium Catch Pan 13

4. Nitrogen Flooding System 13

5. Test Instrumentation 17

C. EXPERIMENTAL CONDITIONS 18

1. Nitrogen Flood Rate Requirement 18

2. Summary of Experimental Conditions 21

IV. RESULTS AND DISCUSSION 23

A. NARRATIVE OF EVENTS 23

B. RESULTS DURING FIRE PERIOD 24

1. Nitrogen Flooding System Operation 26

2. Sodium Pool Temperature 28

3. Mockup Gas Temperature 28

4. Temperature of Insulating Brick 32

5. Pressure Differential 32

6. Oxygen Concentration 35

7. Sodium Oxide Aerosol 39

8. Smoke Abatement Evaluation 42

c. POST-TEST EXAMINATION 43

1. General 43

2. Sodium Residue 45

3. Test Cell Leak Rate 49

V. REFERENCES 49

VI. ACNOMECEVENIS 49

APPEND ICES

APPENDIX A - INSTRUMENT SENSOR LOCATIONS A-1

APPENDIX B - NARRATIVE OF KEY TEST EVENTS AND OBSERVATIONS $\quad B-1$ 
Figure

IUUSTRATIONS

Number

Page

1. Plan View of Large Sodium Fire Facility 6

2. Ventilation Flow Diagram - $E$ LL Large Sodium Fire Faci ity 7

3. Conceptual Diagram of Experimental Arrangement 9

4. Pipeway Mockup Installed In The Large Fire Room - Plan View 10

5. Pipeway Mockup Installed In The Large Fire Room - Elevation View 11

6. Pretest View 0 f Burn Pan Installed In Mockup 12

7. Pretest View 0 f Burn Pan Installed On Insulating Firebrick 14

8. Liquid Nitrogen Vaporizing Station 15

9. Nitrogen Flow Control Station 16

10. Instrument Data Output During Fire Period 25

11. Effect $O f$ Nitrogen Flooding Rate On Mockup Differential Pressure 27

12. Sodium Pool Temperatures During Initial 80-Minute Period 29

13. Long-Term Temperatures and Oxygen Relationship 30

14. Gas Temperatures Above Sodium Pool 31

15. Temperature of Mockup Gas Space 33

16. Temperature of Insulating Firebrick 34

17. Oxygen Concentration In The Mockup Atmosphere During The First Hour $\mathbf{3 6}$

18. Oxygen Concentration In The Mockup Atmosphere A t Long Time 40

19. Sodium Oxide Aerosol Concentration 41

20. View of Burn Pan With Sodium Residue 44

21. Closeup View 0 f Oxide Crust 46

22. Ignition 0 f Sodium Residue Crust During Sampling 47

23. Mockup Leak Rate 50

24. Mockup Floor Cleanup Operations 51

Table

TABLES

Number

I. Summary of Test Conditions For Test F2 22

II. Nitrogen Flood History 26

III. Mass Spectrometer Analysis of Mockup Atmosphere 42

IV. Sodium Mass Balance $\quad 48$

V. Summany of Chemical Forms 48 
SODIUM FIRE CONTROL BY SPACE ISOLATION

WIH NITROGEN FLOODING - FFTF PROOF TEST F2

\section{INTRODUCTION}

The secondary sodium equipment and piping in the Fast flux Test Facility (FFTF) are located in an air atmosphere. While the possibility of a large sodium spill is highly unlikely, the consequences of such an occurence make it desirable to provide some level of fire protection to reduce equipment loss, plant down time, and the hazard to personnel. Fire protection in the FFTF ex-containment sodium areas is provided by space isolation with nitrogen flooding (1). Isolating the space in which the sodium spill occurs causes oxygen depletion due to burning sodium. The purpose of the nitrogen flood is not to purge the space free of oxygen, although this occurs to some extent, but to maintain a slight positive cell pressure to prevent inleakage of oxygen.

Space isolation in ex-containment areas of the FFTF is achieved by locating sodium equipment and piping in reasonably gas-tight rooms, cells and pipeways. Walls, partitions, fire doors, ventilation dampers and penetration seals provide this feature. Normal air flow to these areas is supplied by heating and ventilating ducts which contain automatically activated dampers. A sodium spill will rapidly produce the dense aernonl of sndium oxide smoke characteristic of sodium fires ${ }^{(2)}$ and will activate a smoke detection system, which in turn closes the dampers. Pressure relief vents are provided in each space to prevent overpressurization. During the early stages of the fire, burning of the sodium will partially deplete the oxygen content of the cell atmosphere and heat will be transferred to the cell atmosphere, causing a slow expansion and escape of smoke through the cell leakage points and the pressure relief damper. During this time the inert gas flooding system is manually activated and gaseous nitrogen at ambient temperature and pressure is injected into the cell. For the FFTF, the nitrogen source is a liquid nitrogen storage facility with atmospheric vaporizers. 
The flow rate of nitrogen into the affected fire area is monitored by a flowmeter and maintained at a predetermined rate by a manual control valve. It is desirable to minimize the rate at which nitrogen is injected in order to reduce the discharge of smoke from the cell and to reduce the cost of the nitrogen supply system. However, it is important that the rate be sufficiently high that a slight positive pressure is maintained.

A proof test (F2) was performed in the HDL Large Sodium Fire Facility (LSFF) to demonstrate that space isolation with nitrogen flooding can extinguish a large sodium fire and to verify the nitrogen flooding rate for the FFTF. An earlier test (FI.) in the LSFF had provided a basis for comparison. In test $\mathrm{FI}$ approximately 100 gallons of $1100^{\circ} \mathrm{F}$ sodium were spilled onto a concrete surface within a full scale mockup of an FFTF pipeway. All of the sodium reacted. The experimental conditions for test F2 were similar, except that a shallow steel catch pan was provided to contain the spill and a nitrogen flood was activated. The results of test $\mathbf{F 2}$ are the subject of this report.

\section{SUMMARY AND CONCLUSIONS}

Test F2 simulated a major sodium spill in an FFTF pipeway containing a normal air atmosphere. The pipeway was a full scale mockup $\left(3350 \mathrm{ft}^{3}\right)$ but the quantity of sodium spilled was considerably less than the maximum possible in the event of a major breach of the sodium piping. The quantity of sodium spilled (100 gallons) was 5 to 10 times the amount required to react stoichiometrically with the initial oxygen content of the air in the pipeway and thus is considered adequate for the purpose of the test. The mockup was constructed of sheet metal with exterior thermal insulation rather than the massive concrete of an actual pipeway. The leak tightness of the mockup was measured by injecting nitrogen at various rates and measuring the steady state differential pressure at each injection rate. The leakage rate was adjusted prior to the test to match that expected for the FFTF--approximately one cell volume per hour at 0.1 inch $\mathrm{H}_{2} \mathrm{O}$ differential pressure.

The sodium was preheated to $1100^{\circ} \mathrm{F}$ and $770 \mathrm{Ib}$ were spilled rapidly into a $4 \mathrm{ft}$ by $8 \mathrm{ft}$ steel catch pan located within the pipeway mockup. 
The sodium ignited immediately upon contact with the air. A small pressure pulse (1.4 in. $\mathrm{H}_{2} \mathrm{O}$, maximum) was measured during the 20 -second spill, The temperature of the sodium was chilled to $840^{\circ} \mathrm{F}$ by heat exchange with the cold catch pan, and then slowly increased due to the heat of combustion of the burning sodium. A maximum pool temperature of $1050^{\circ} \mathrm{F}$ was attained at 25 minutes after the spill.

Nitrogen flooding was started fifteen minutes after the spill and controlled manually at a constant rate of 60 SCFM until the sodium pool temperature had decreased to $370^{\circ} \mathrm{F}$, when nitrogen flow was terminated. A positive pressure of 0.3 to 0.7 inch $\mathrm{H}_{2} \mathrm{O}$ was measured during the $\mathrm{N}_{2}$ flooding period. The pool temperature continued to decrease after termination of nitrogen flooding even though the oxygen concentration in the pipeway mockup increased slightly.

After the sodium had cooled to ambient 'conditions, samples were taken for chemical analysis and it was found that $100 \mathrm{lb}$ of sodium had reacted, leaving $6701 \mathrm{~b}$ unreacted.

This test demonstrates conclusively that sodium fires can be controlled and extinguished by the method of space isolation with nitrogen flooding in the absence of a sodium-concrete reaction. The test results support the following additional observations and conclusions.

- The sodium fire was effectively controlled and extinguished by the nitrogen flooding operation, About four cell volumes of $\mathrm{N}_{2}$ gas (STP) were used during the 3.5-hr flooding period.

- The maximum temperature attained by the sodium pool was $1050^{\circ} \mathrm{F}$, after an initial chill to $840^{\circ} \mathrm{F}$. The temperature continued to decrease continuously after termination of $\mathrm{N}_{2}$ flooding until the freezing temperature was reached in 15 hours.

- About $100 \mathrm{lb}$ of the $770-\mathrm{lb}$ sodium spill was reacted, $87 \%$ remained in metallic form.

- The differential pressure caused by $\mathbb{N}_{3}$ flooding was always positive and increased with time due to partia 3 plugging of leak points by deposited smoke particles,

- The oxygen concentration in the test cell atmosphere decreased monotonically to 0.02 volume percent at the time $\mathrm{N}_{2}$ flooding was terminated. The $\mathrm{O}_{2}$ concentration then increased to a maximum of $2.7 \%$, at which time a slow reaction caused evolution of smoke and a decrease of $\mathrm{O}_{2}$ to $2 \%$. The sodium temperature continued to decrease, however, and the release of smoke abated without restarting the $\mathrm{N}_{2}$ flood. 
- The steel catch pan appeared not to have leaked. No damage to the pipeway mockup was evident.

- The solid sodium residue in the catch pan was about 5 inches deep and was $292 \%$ metallic sodium. It had a crust of oxide about $3 / 16$ in. thick that was very pyrophoric.

- The sodium wet the sides of the catch pan about 4 in. above the pool level. About $\mathbf{3}$ in. of pan wall remained unwetted except where instrument holders and a painted steel plate provided gaps for capillary action.

- Hydrogen concentration in the mockup atmosphere remained $<0.01 \%$.

\section{II - TEST CONDITIONS}

\section{A. EXPERIMENTAL PROCEDURE}

The procedure used in test F2 was to simulate a major sodium spill in a typical FFTF secondary sodium enclosure initially containing a normal air atmosphere, and to follow the progress of the ensuing fire and associated effects on the test mockup, its environment and the sodium. For this test, an all-steel catch pan with $32 \mathrm{ft}^{2}$ of surface was provided to confine the spilled sodium to a known area. The test mockup was a full scale model of an FFTF secondary sodium system pipeway. It was a reasonably air tight structure equipped with pressure relief and vacuum breaker devices and was provided with a nitrogen flooding system and temperature, pressure and gas sampling instrumentation. .

After an intentional 15-minute delay, the nitrogen flooding system was activated and controlled manually at a predetermined flowrate of 60 standard cu ft per minute (SCFM). When the temperature of the sodium pool dropped below $400^{\circ} \mathrm{F}$, the nitrogen flow was terminated. When the temperature had subsided to approximately $100^{\circ} \mathrm{F}$, the a ir leakage rate of the mockup cell was measured at various differential pressures for comparison with pre-test leakage measurements. The cell was then entered for sampling and inspection. Samples were analyzed chemically and a material balance was made, Finally, the mockup and fire room were cleaned by sweeping and rinsing with water. 


\section{B. EXPERIMENTAL EQUIPMENT}

1. Description of the LSFF

The Large Sodium Fire Facility (LSFF) provides a means for investigating on a significant engineering scale the fire and safety aspects associated with large sodium fires in LMFBR facilities. Its principal features are two concrete fire rooms; equipment for storing, transferring, heating and discharging molten sodium; a ventilation system for controlling air movement and limiting sodium smoke effluent; a liquid nitrogen storage, vaporizing and flow monitoring system; and instrumentation for operational controls and gathering test data.

Figure 1 shows a plan view of the work area of the LSFF. Testing is performed in a Large Fire Room which measure $27 \mathrm{ft}$ by $20.5 \mathrm{ft}$ by $21 \mathrm{ft}$ high. The walls, floor and ceiling are of unpainted 12-in. thick reinforced concrete. Observation windows are provided in the steel doors to the fire room. The room is ventilated by outside air during the tests. The ventilation air, containing sndium nxide smoke from the test mockup, leaves the room via an exhaust duct with an orifice flowmeter and enters a large Exhaust tunnel leading to the exhaust fan. Dilution air can be added in the tunnel. The fan is rated at 10,000 SCFM at $250^{\circ} \mathrm{F}$. Figure 2 shows a schematic diagram of the ventilation system. From the fan, the air stream passes through about $150 \mathrm{ft}$ of tunnel to a water scrubber, a high efficiency particulate air (HEPA) filter bank and a $200-\mathrm{ft}$ stack.

The sodium was procured in 400-lb drums, melted in portable drum melters and charged tu a 900-gallon batch tank which is located in a room adjoining the Large Fire Room. The tank can be weighed by load cells before and after the sodium transfer to determine, to $\pm 4 \%$ accuracy, the quantity of sodium spilled. Argon cover gas pressure is used to discharge the sodium via a 4-in. diameter pipe equipped with a pneumatic operated isolation valve. External electric heaters on the batch tank are capable of heating the sodium to $1200^{\circ} \mathrm{F}$. 


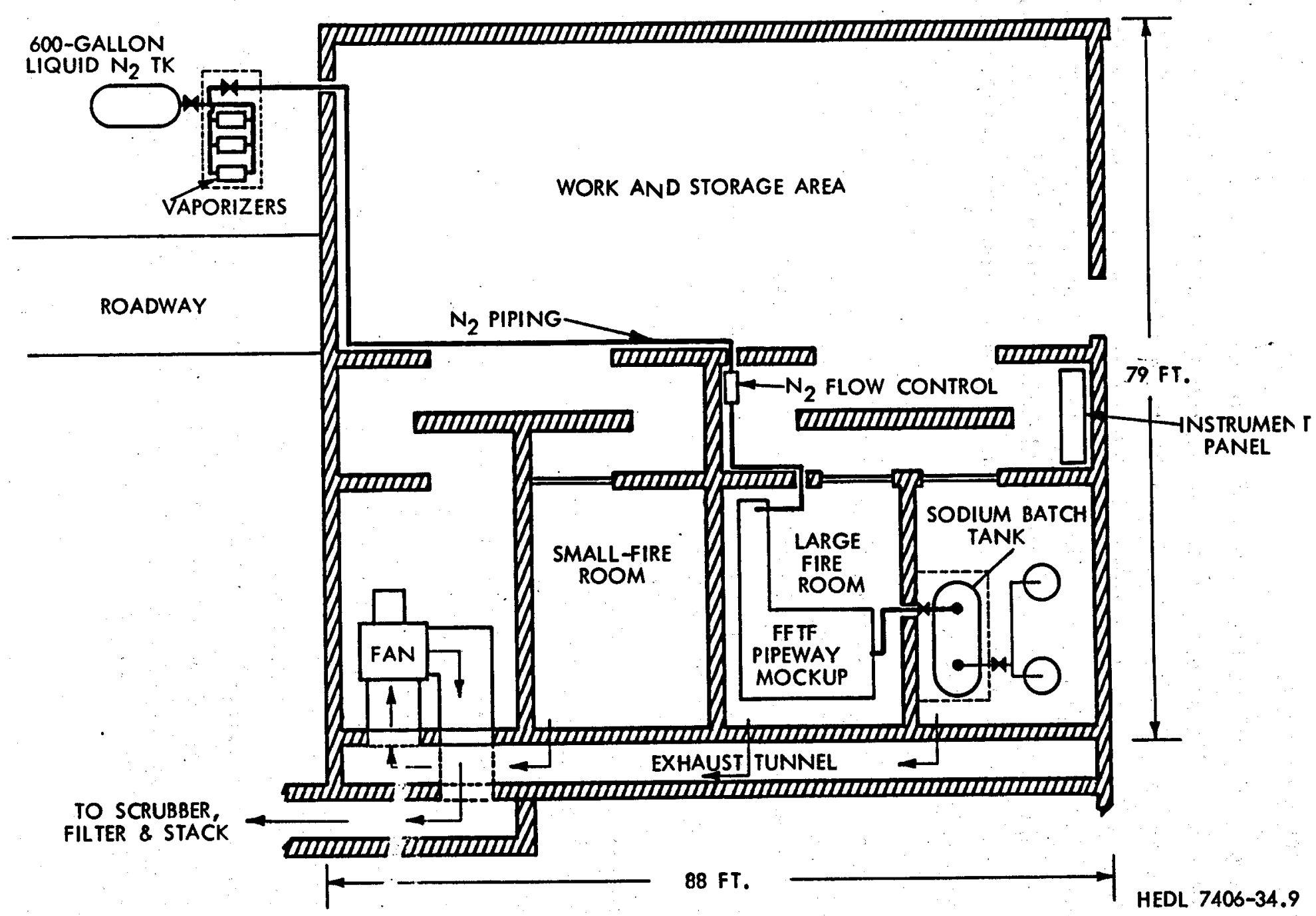

FIGURE 1. Plan View of Large Sodium Fire Facility 

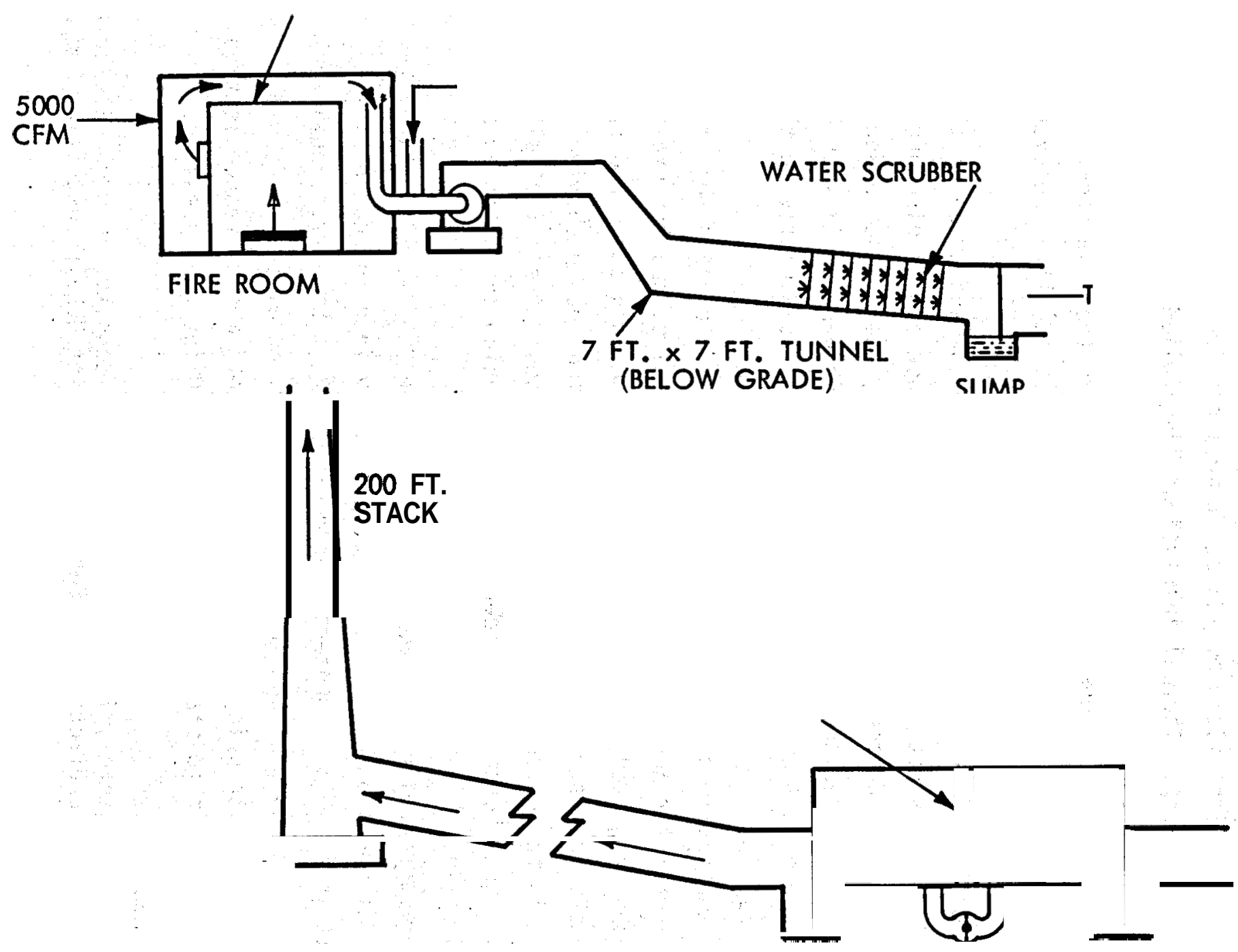


\section{FFTF Pipeway Mockup}

An FFTF secondary sodium pipeway was mocked up within the Large Fire Room. A conceptual diagram is given in Figure 3. The full scale mockup is fabricated of 16-gauge sheet metal with standing rib seams for stiffeners. The floor and bottom $12 \mathrm{in.}$ of wall are 1/4-in. carbon steel plate welded to form a leak-tight floor of $185 \mathrm{sq} \mathrm{ft}$ area resting directly on the fire room concrete floor. Thermal insulation* was applied to all exterior surfaces of the mockup. Figure 4 is a plan view and Figure 5 is an elevation view of the pipeway mockup installed in the fire room. The plan dimensions are $10 \mathrm{ft}$ by $15 \mathrm{ft}$ with a $12-\mathrm{ft}$ by $3.5-\mathrm{ft}$ ell. The overall height is $18 \mathrm{ft}$.

A heat-traced 3-in. diameter pipe connects the sodium batch tank with the mockup. It is not heat traced within the mockup. It discharges directly over the center of the steel catch pan, ending open ended at a distance of 7 inches above the floor of the catch pan. A 24-inch diameter splash guard with four 6 -inch diameter notches rests directly on the floor of the pan.

The two sodium pipes that run through the FFIF pipeway were mocked up by 34-in. diameter sheet metal dummy pipes that simulated the exterior diameter of the insulated pipe. The dummy pipes were open ended and tack welded to the mockup walls. Figure 6 gives a view of the mockup showing the sodium catch pan installed beneath one of the dummy pipes. The 3-in. spill pipe and splash guard can also be seen. The small tubing in the foreground is a gas sample line.

A pressure relief vent was installed in the 3.5-ft. wide ell of the mockup. It opens outward only, venting directly in to the Large Fire Room. It is a 5-blade counterbalanced damper, $3 \mathrm{ft}$ by $3 \mathrm{ft}$, manufactured by the American Warming and Ventilating Company, Model SHW-2230, with silicone rubber stripping on the blade edges and jambs to reduce leakage. The damper was set to start opening at 2 -in. $\mathrm{H}_{2} \mathrm{O}$ internal pressure.

\footnotetext{
* Glass fiber blanket, 1 in. thick, $1.5 \mathrm{lb} / \mathrm{ft}^{3}$ density, $\mathrm{k}=0.027 \mathrm{Btu} / \mathrm{hr}-\mathrm{ft}$ ${ }^{\circ} \mathrm{F}$ at $150^{\circ} \mathrm{F}$, manufactured by Certain-Teed Sa $\mathrm{nt}$ Gobain Insulation Company, Valley Forge, $\mathrm{Pa}$.
} 


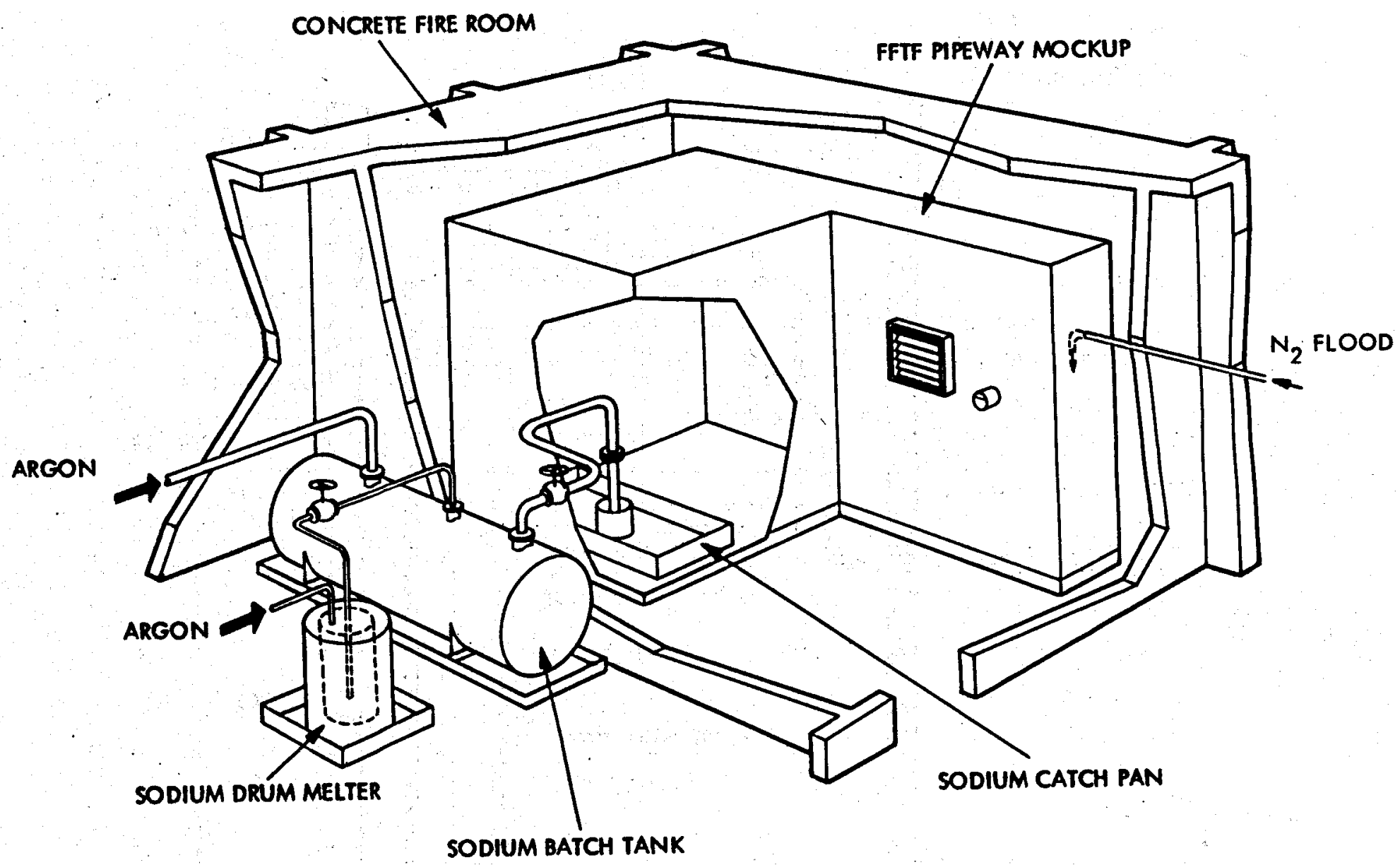

HEDL 7303-21

F\&GURE 3. Conceptual Diagram of Experimental Arrangement 


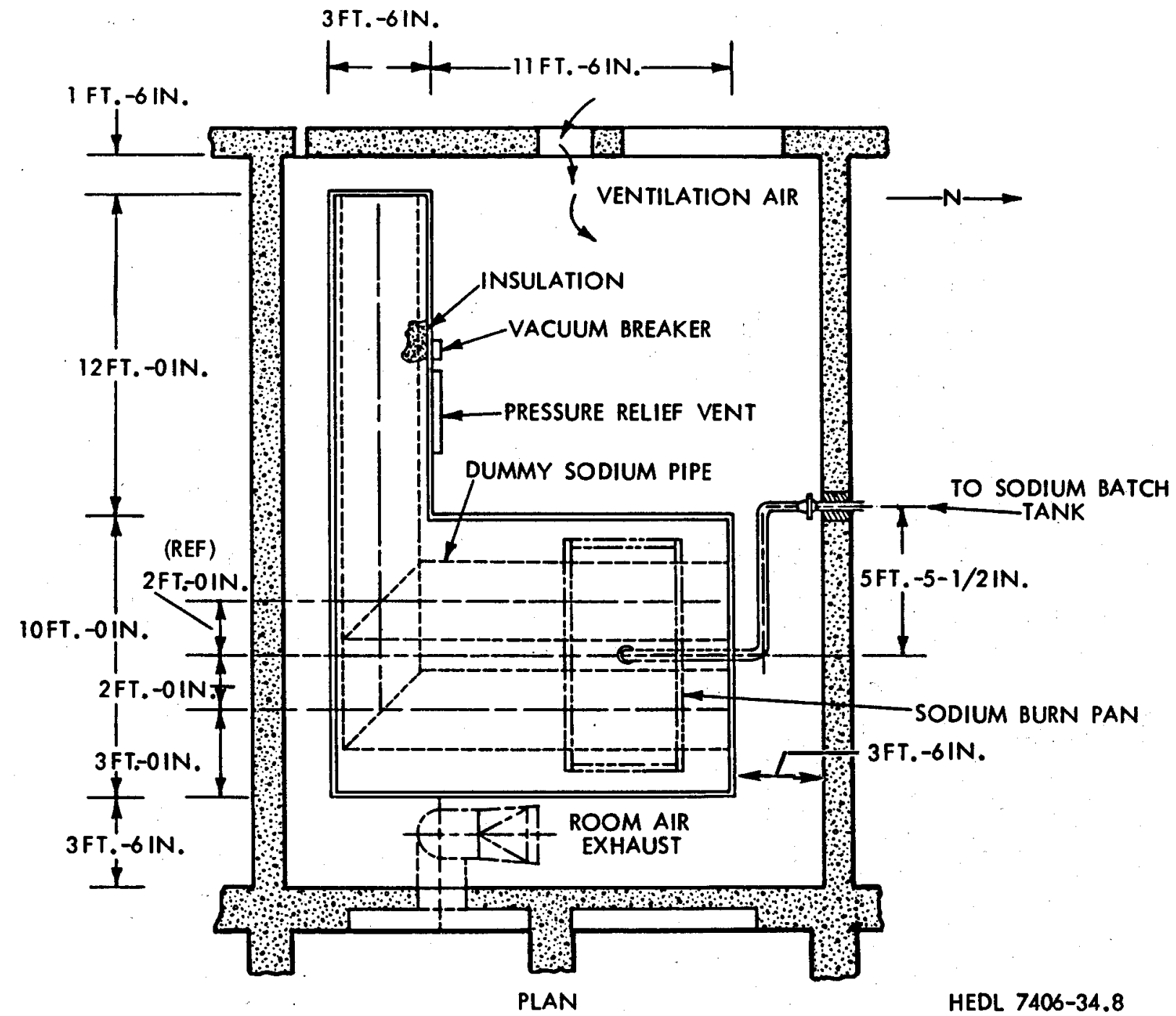

FIGURE 4. Pipeway Mockup Installed in the Large Fire Room - Plan View 


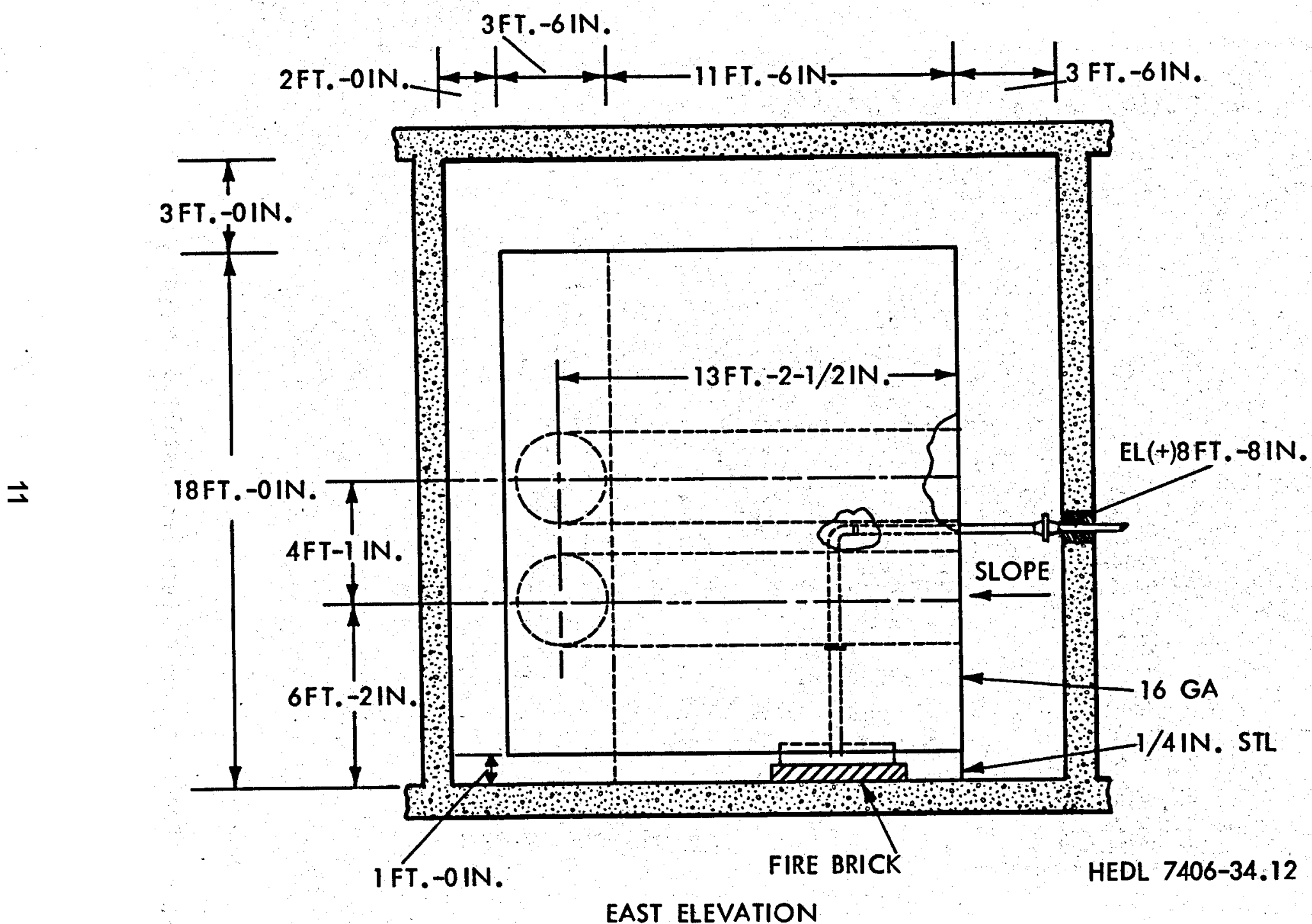

FIGURE 5. Pipeway Mockup Installed in the Large Fire Room - Elevation View 


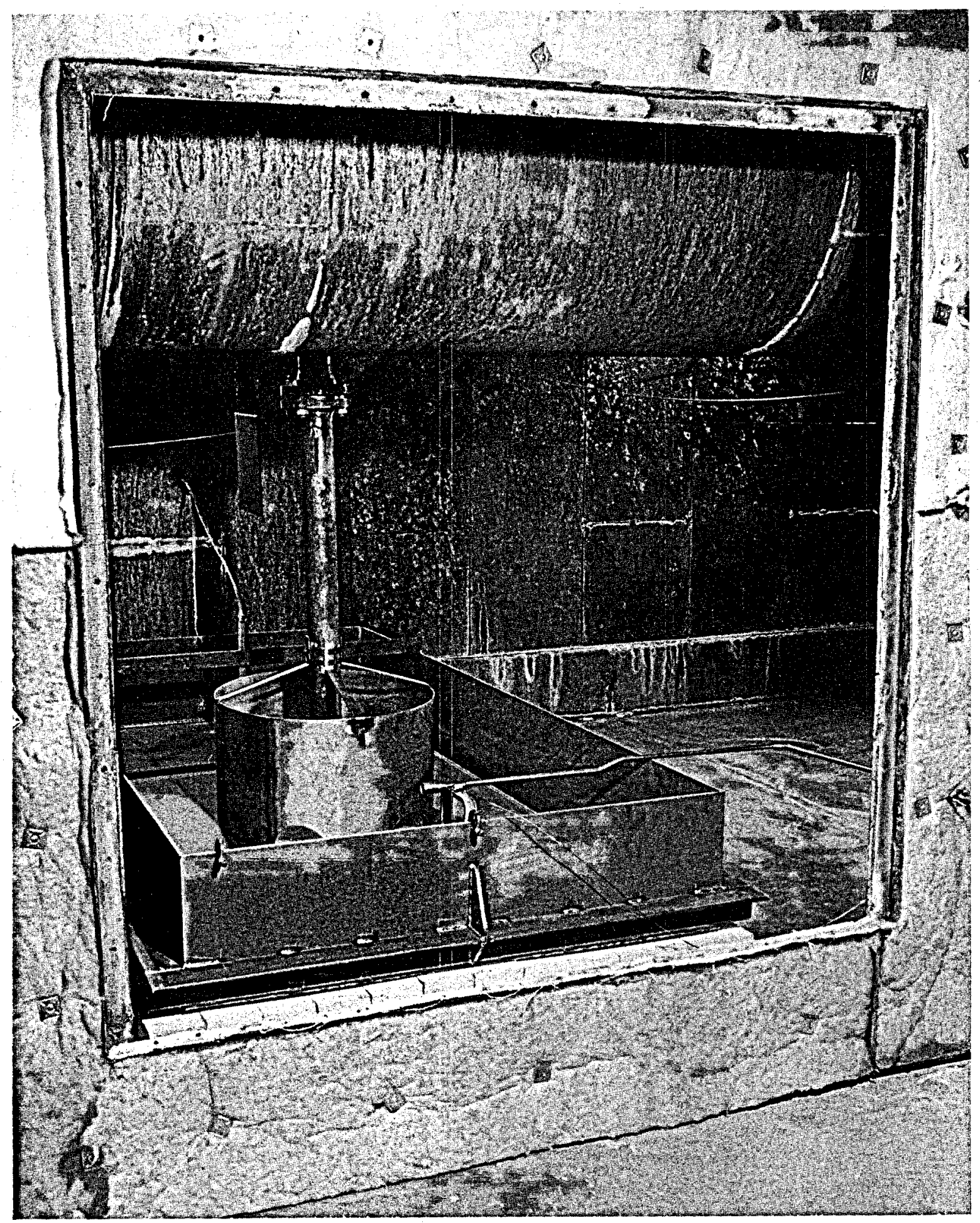

73 HO 228-19

FIGURE 6. Pre-test View of Burn Pan Installed in Mockup 
The leak rate of the entire pipeway mockup was adjusted to 200 SCFM at 0.5 in. $\mathrm{H}_{2} \mathrm{O}$ differential pressure, measured at $70^{\circ} \mathrm{F}$. This is approximately the leak rate expected in the actual FFTF pipeway. Assuming that the mass leak rate is proportional to the square root of the gas density, the leak rate at the maximum expected cell gas temperature of $700^{\circ} \mathrm{F}$, which could be attained during a fire, is calculated to be 135 SCFM at 0.5 inches $\mathrm{H}_{2} \mathrm{O}$. The leak rate was measured by injecting nitrogen at known rates and measuring the pressure differential at steady state. The pre-test leak rate was dependent on pressure according to Equation (1).

$$
Q_{L}=300 \text { (DP) } 0.6
$$

where: $Q_{L}=$ leak rate, SCFM

$$
D P=\text { differential pressure, in. } \mathrm{H}_{2} \mathrm{O}
$$

3. Sodium Catch Pan

The sodium catch pan was made of $1 / 4$ inch ASTM A-36 carbon steel plate. It s dimensions were $4 \mathrm{ft}$ by $8 \mathrm{ft}$ by $1 \mathrm{ft}$ high. Figure 7 is a photograph of the catch pan installed in the pipeway mockup. It rests on three courses of insulating brick". Some of the thermocouple and gas sample instrumentation is visible.

\section{Nitrogen Flooding System}

The nitrogen flooding system consisted of a 600 -gal. liquid $\mathrm{N}_{2}$ storage tank, three atmospheric vaporizers, approximately $100 \mathrm{ft}$ of $1-1 / 4-$ in. steel pipe, and a flow control and monitoring station. Figure 8 is a photograph of the liquid $\mathrm{N}_{2}$ tank and vaporizers, Gaseous $\mathrm{N}_{2}$ at $100 \mathrm{psig}$ flows from the vaporizers through the pipe, as shown in Figure 1. The flow control station is shown in Figure 9. The flow rate was controlled by a 1-1/4-in. 'manual globe valve and the rate was measured by an axial turbine flow tranducer** which read out on a meter and a recorder. Flow rate readings were accurate to $\pm 5 \%$ in the range of 10 to 250 SCFM

* A.P. Green type G-23, size $4.5 \times 2.5 \times 9, \mathrm{k}=0.13 \mathrm{Btu} / \mathrm{hr}-\mathrm{ft}-{ }^{\circ} \mathrm{F}$ at $400^{\circ} \mathrm{F}$, bulk density $45 \mathrm{lb} / \mathrm{ft}^{3}$. Manufactured by A.P. Green Refractories Co., Mexico, Missouri.

** Model FT-16.-N-50-AGB, manufactured by Flow Technology, Inc. , Tempe, Arizona. 


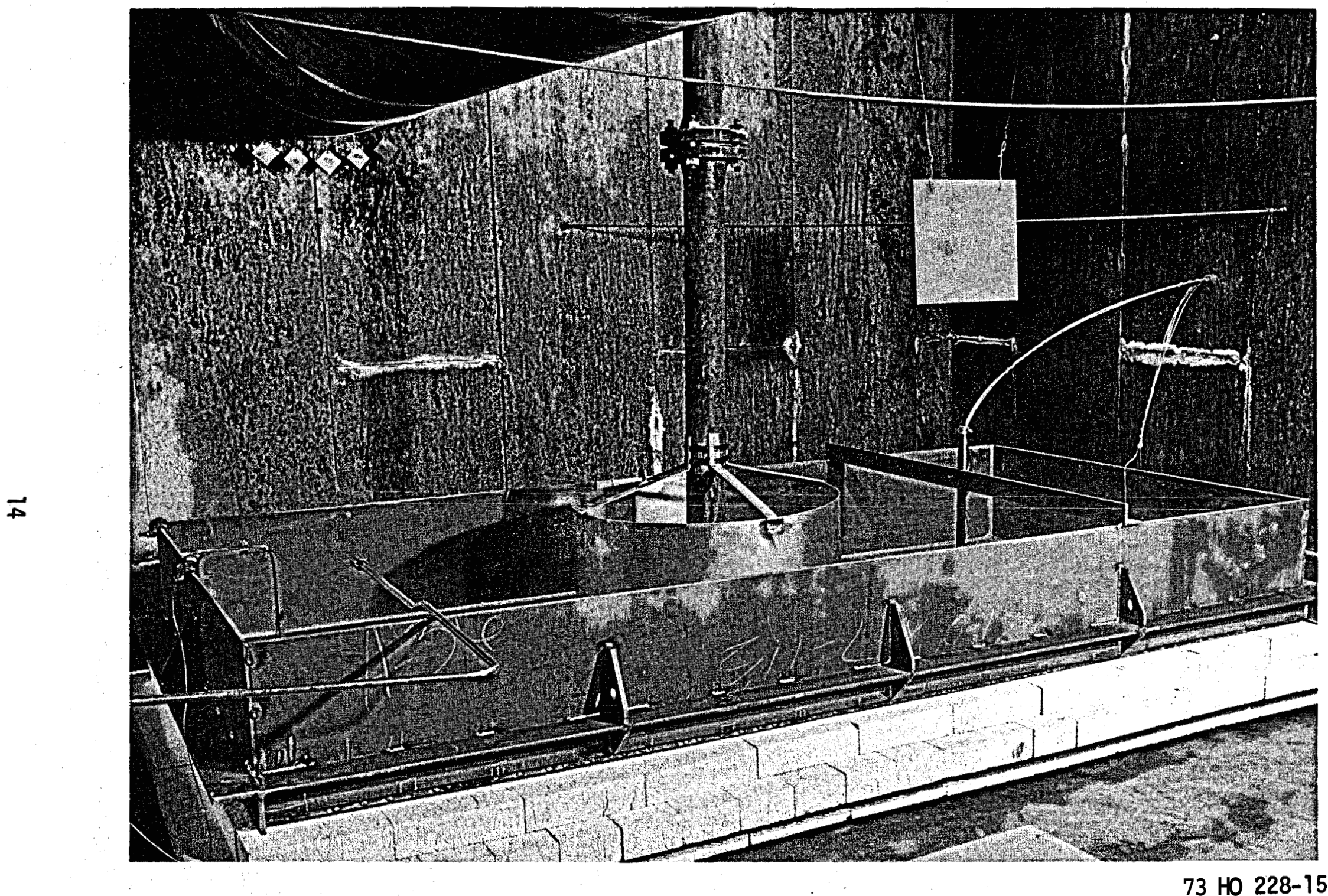

FIGURE 7. Pre-test View of Bum Pan Installed an Insulating Firebrick

C . 

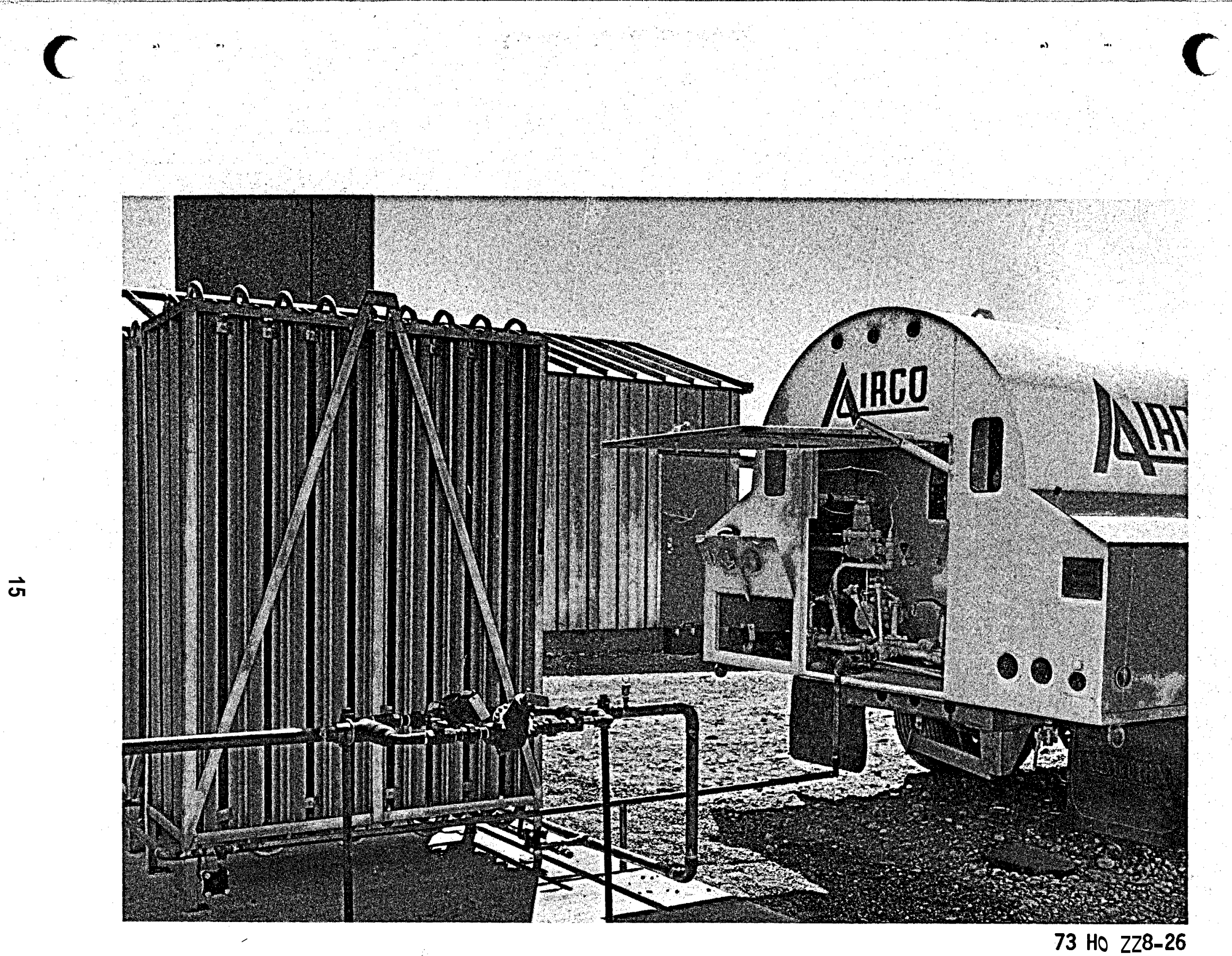

FIGURE 8. Liquid Nitrogen Vaporizing Station 


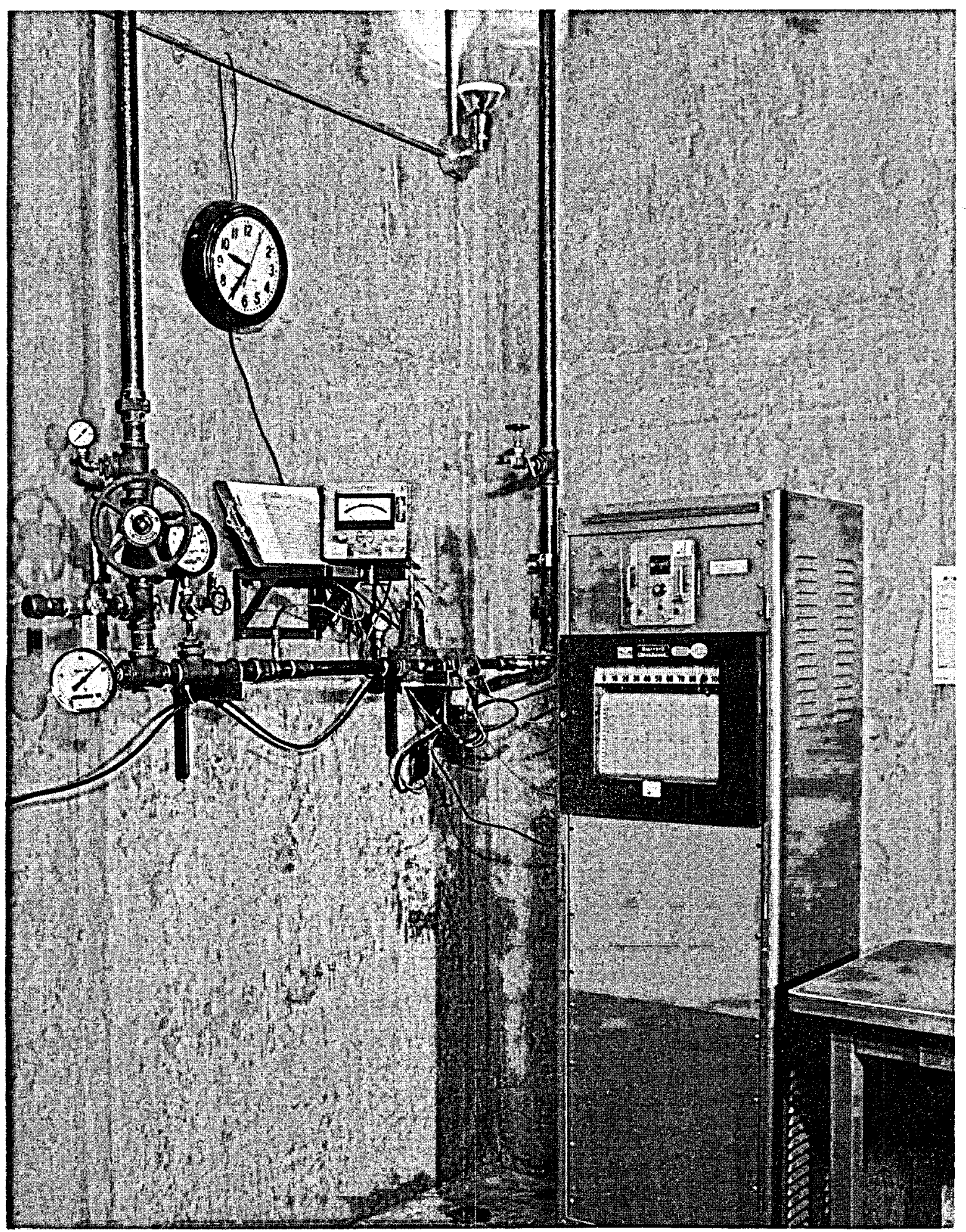

73 HO 228-23

FIGURE 9. Nitrogen Flow Control Station 
The terminus of the $N_{2}$ flood pipe was located at the extreme west end of the 3.5-ft wide ell (see Figure 1). No attempt was made to apply the nitrogen gas directly to the burning sodium. The 1-1/4 in. pipe terminated open ended $12 \mathrm{ft}$ above the mockup floor, with flow directed downward.

\section{Test Instrumentation}

Temperature measurements were made by 29 Chromel-Alumel thermocouples with stainless steel sheaths. The locations of the hot junctions are given in Appendix A. Readout was by multipoint strip chart recorders.

Oxygen and hydrogen analyses of the gaseous atmosphere in the pipeway mockup were obtained by pumping gas from three locations through tubing to on-line analyzers. The lines were manifolded so that any one of the three locations could be valved in for analysis, but only one location could be analyzed at a time. A Beckman Model $\mathbf{7 4 2}$ oxygen analyzer was used, with output to a strip chart recorder. The analyzer was calbrated during the test by valving in normal room air $\left(20.95 \% 0_{2}\right)$ or bottled argon (zero $\%_{2} \mathrm{O}_{2}$ ). The hydrogen analyzer was an MSA thermatron, Model T-3, which used the thermal conductivity principle. It was calibrated with $2.1 \% \mathrm{H}_{2}$ in dry nitrogen. Gas sample location coordinates are given in Appendix A. Samples were taken from the burn pan, near the ceiling over the burn pan and near the floor in the extreme end of the 3.5-ft ell.

In addition to the on-line $\mathrm{O}_{2}$ and $\mathrm{H}_{2}$ analyzers, grab samples were taken periodically and analyzed by mass spectrometer.

Differential pressure was measured by two transducers. One was located $14 \mathrm{ft}$ above the mockup floor, the other 6 in. above the mockup floor.

Val idyne Model DP45 variable reluctance pressure transducers with \pm in. $\mathrm{H}_{2} \mathrm{O}$ range were used for measurements sensitive to 0.005 in. $\mathrm{H}_{2} \mathrm{O}$. A Validyne Model DP15 pressure transducer with \pm 0.5 psi range was used during the sodium spill when higher pressures were expected. Readings were recorded on a Brush multispeed recorder.

The mass concentrations of sodium oxide aerosol at five locations were measured by pulling known volumes of gas through a Gelman Type A glass fiber filter and analyzing the filter for sodium by flame spectrophotmetry. 
Sample flow was 0.5 CFM provided by vacum pumps through 1/2-in. diameter tubing, 1/2-in. ball valve, filter holder and rotameter. Sample lines ranged from $2 \mathrm{ft}$ to $25 \mathrm{ft}$ long. The location of the five aerosol sample points is given in Appendix A.

\section{EXPRIMNTAL CONDIIONS}

1. Nitrogen Flood Rate Requirement

Oxygen re-entry to the enclosed space can occur by four mechanisms:

1) Forced convection, as by a cell ventilation system,

2) Cooling of enclosed gas,

3) Diffusion of $\mathrm{O}_{2}$ due to concentration gradient, and

4) Natural convective flow due to chimney effect.

A basic premise of the concept of fire protection by space isolation is that mechanism (1) will be eliminated or made negligible. In this analysis it will be assumed negligible, but this should be verified for the actual plant condition.

Cooling of Enclosed Gas. - Equation (2) can be derived from the ideal gas law assuming that the cell gas is uniform in temperature and that constant pressure and volume conditions prevail.

$$
Q_{c}=\frac{360 P V}{R T^{2}} \frac{d T}{d t}
$$

where: $\quad Q_{c}=$ nitrogen inflow rate required to compensate for cooling of the enclosed gas, $\mathrm{ft}^{3} / \mathrm{min}$ at STP

$\mathbf{P}=$ absolute pressure of enclosed gas, psia

$\mathrm{V}=$ volume of enclosed gas, $\mathrm{ft}^{3}$

$\mathrm{R}=$ gas constant

$\mathbf{T}=$ absolute temperature of enclosed gas, ${ }^{\circ} \mathbf{R}$

$\mathbf{t}=$ time, $\min$.

The cooling rate, $d T / d t$, and the cell gas temperature can be estimated by a heat transfer analysis which incorporates the heat of chemical 
reaction. The SOFIRE II computer code (4) can be adapted for this purpose. For the conditions of test F2, $Q_{c}=2.8$ SCFM maximum.

Oxygen Diffusion. - A second mechanism for oxygen entry is by diffusion through leak points due to the oxygen concentration gradient. Fick's first law can be used to calculate the rate of diffusion if the concentration gradient and the convective flow are known or can be estimated. The concentration gradient depends on the difference in oxygen concentration between the cell and outer room atmospheres and the geometry of the leak path.

Fick's first law, for stationary coordinates and zero $0_{2}$ diffusion, gives

$$
N_{B}=\frac{C D_{A B}}{X_{A}} \frac{\Delta X_{A}}{\Delta Z} \text {. }
$$

where: $\quad N_{8}=$ flux of $N_{2}$ through leak paths, $\frac{1 \mathrm{~b}-\mathrm{mol}}{\mathrm{hr} \mathrm{ft}^{2}}$

$X_{A}=$ mol fraction oxygen

$c=$ molar concentration of all gases, $1 \mathrm{~b} \mathrm{~mol} / \mathrm{ft}^{3}$

$D_{A B}=$ diffusion coefficient of $\mathrm{O}_{2}$ in air, $\mathrm{ft}^{2} / \mathrm{hr}$

$\Delta X_{A}=$ difference in mol fraction of $\mathrm{O}_{2}$ across leak path

$\Delta z$ = length of leak path, $\mathrm{ft}$.

For test F2, $\Delta z$ is the thickness of the gasket material on the pressure relief damper, $\sim 1 / 8 \mathrm{in}$., and $N_{B}$ is calculated to be $0.005 \mathrm{lb}-$ mole $\mathrm{N}_{2} / \mathrm{ft}^{2}$ min.

$N_{B}$ is the minimum flux of nitrogen flowing out of the cell which will just prevent inflow of oxygen by diffusion. The volumetric flow can be calculated by Equation (4) if the cross-sectianal area of the leak paths can be estimated.

$$
Q_{D}=360 \mathrm{~N}_{B} \mathrm{~A} \text {. }
$$

where: $\quad Q_{D}=$ nitrogen outflow rate, $\mathrm{ft}^{3} / \mathrm{min}$ at STP

$A=$ total leak-path cross-sectional area, $\mathrm{ft}^{2}$. 
Assuming that the specification for cell leak tightness can be expressed by Equation (5) and orifice flow prevails, the total leak area is calculated to be approximately $A \approx 0.00003 \mathrm{~V}$ and from equation (4), the minimum outward flow rate of nitrogen from the cell required to prevent oxygen inward diffision is approximately 0.2 SCFM, which is negligible compared to other mechanisms.

$$
\frac{Q_{L}}{V}=\frac{2(D P)^{0.5}}{T^{0.5}}
$$

where: $Q=$ cell leak rate at $T^{\circ} \mathrm{R}, \mathrm{ft}^{3} / \mathrm{min}$

$$
\begin{aligned}
\mathrm{DP} & =\text { pressure difference across cell wall, in. } \mathrm{H}_{2} \mathrm{O} \\
\mathrm{T} & =\text { absolute temperature of cell gas, }{ }^{\circ} \mathrm{R} .
\end{aligned}
$$

Chimney Effect. - The cell gas is at a higher temperature than the surrounding air. Therefore, the effect of elevation on pressure will be less in the enclosure than in the more dense outside air. Assuming that the cell gas is uniform in temperature,

$$
\frac{d P}{d y}=\frac{P(M W)}{R T}
$$

where: $y=$ elevation above cell floor, $\mathrm{ft}$ $\mathrm{MN}=$ molecular weight of cell gas .

For normal atmospheric pressure and uniform cell temperature

$$
\Delta(D P)=7.45 \Delta y\left(T_{0}^{-1}-T_{i}{ }^{-1}\right)
$$

where: $\quad T_{0}=$ temperature of air outside the cell, ${ }^{\circ} \mathrm{F}$

$\mathrm{T}_{\mathbf{j}}=$ temperature of enclosed cell gas, ${ }^{\circ} \mathrm{F}$. $\Delta(D P)=$ difference in DP at two elevations, in. $\mathrm{H}_{2} \mathrm{O}$

$A y=$ elevation difference, $\mathrm{ft}$.

For test F2 conditions, $\Delta$ (DP) was predicted by Equation (7) to be 0.072 in. $\mathrm{H}_{2} \mathrm{O}$. This means that, in order to keep the DP at zero at the floor of the mockup, a positive pressure of 0.072 in. $\mathrm{H}_{2} \mathrm{O}$ needed to be maintained at the ceiling of the 18-ft. high cell. Using Equation (5) as the expression relating leakage rate to DP, a nitrogen injection rate of 44 SCFM would give the required DP to compensate for the chimney effect. 
It is important to note that the chimney effect can induce oxygen inleakage even when the temperature and pressure is invariant with time. All that is necessary is a temperature difference between the enclosed and outer atmospheres and leak points at difference elevations.

Total Flood Rate. - If the nitrogen flood gas is injected at a predetermined constant rate, the rate must be high enough to prevent oxygen entry by all mechanisms operating simultaneously. Oxygen diffusion is negligible compared with cell cooling and chimney effect in early stages of a fire when temperatures are high. However, 'because it is relatively independent of temperature, diffusion may be the most important mechanism operating after the cell has cooled. For the conditions predicted for test F2, the maximum flood rate required to maintain zero DP is 47 SCFM. Allowing a safety factor of 1.25, a flooding rate of 60 SCFM was specified for test F2.

The foregoing analysis is based on the assumption that the leak path area will remain constant during a fire. Precautions must be taken in design to ensure that the sodium spill and ensuing fire do not decrease the cell leak tightness. Plugging of the leak paths by sodium oxide smoke may occur, but this will be a beneficial effect.

2. Summary of Experimental Conditions

The important experimental conditions are summarized in Table $I$. 
SUMMARY OF TEST CONDIIONS FOR TEST F2

Mass of sodium spilled

,Temperature of sodium prior to spi11

Temperature of sodium 2 min after spill

Duration of spill flow

Average spill flow rate

Batch tank cover gas pressure

Burn pan dimensions

Sodium-air interfacial area

Burn pan material

Test cell total enclosed volume

Test cell floor area

Test cell walls and ceiling

Test cell floor and $12 \mathrm{in}$. high walls

Test cell insulation

Dmmy pipes in test cell

Large Fire Room total volume

Large Fire Room floor area

Ventilation flow through fire room

Temperature of room inlet air

Dew point of room inlet air

Barometric pressure

Total air flow to scrubber

$\mathrm{N}_{2}$ flood start time

$\mathrm{N}_{2}$ flood flowrate

$\mathrm{N}_{2}$ flood terminated

Volume of $\mathrm{N}_{2}$ used

Temperature of $\mathrm{N}_{2}$ gas
$770 \neq 30 \mathrm{lb}$

$1100^{\circ} \mathrm{F}$

$845^{\circ} \mathrm{F}$

$20 \mathrm{sec}$

$300 \mathrm{gpm}$

$9.5 \mathrm{psig}$

$4 \mathrm{ft} \times 8 \mathrm{ft} \times 1 \mathrm{ft}$

$31.5 \mathrm{ft}^{2}$

$1 / 4$ in. C.St1., ASTM A-36

$3350 \mathrm{ft}^{3}$

$185 \mathrm{ft}^{2}$

16 ga. C. St1.

$1 / 4$ in. C. Stl.

1 -in. fiberglass blanket

34 in. D, 16 ga. Stl.

$11,620 \mathrm{ft}^{3}$

$553 \mathrm{ft}^{2}$

$5000 \pm 200 \mathrm{SCPM}$

$85 \pm 2^{\circ} \mathrm{F}$

$45^{\circ} \mathrm{F}$

29.54 in. $\mathrm{Hg}$

$9800 \pm 500$ SCFM

15 min after Na spill

$60.8 \pm 2.1$ SCAM

236 min after $\mathrm{Na}$ spill

12,100 SCF

$79^{\circ} \mathrm{F} \pm 2^{\circ} \mathrm{F}$ 


\section{RESULTS AND DISCUSSION}

\section{A. NARRATIME OF EVENTS}

During sodium spill, the sodium flowed in to the catch pan with very little splashing. Incandescent particles of oxidizfng sodium droplets showered out of the catch pan onto the pipeway mockup floor, but this represented insignificant mass. The spill lasted 20 seconds at an average flowrate of 300 gpm. The TV view of the pan was obscured by smoke within 10 seconds after completion of the spill. The spill was nearly identical visually to that in test $F$ I (3) which had a concrete bottom in the catch pan. The sodium was chilled from $1100^{\circ} \mathrm{F}$ in the batch tank to $845^{\circ} \mathrm{F}$ two minutes after start of spill.

The maximum pressure during the spill was 1.4 in. $H_{2} 0$ attained 26.5 sec after start of spill and coincided with the end of sodium delivery. Smoke was first seen issuing from the mockup pressure relief vent at 30 seconds, and seemed to consist of very small particles.

The period of time between the end of sodium spill and start of $\mathrm{N}_{2}$ flooding at $\mathbf{t}=15 \mathrm{~min}$ was characterized by a slow increase in sodium pool temperature to $1025^{\circ} \mathrm{F}$; an increase in the mockup atmosphere temperature to $240^{\circ} \mathrm{F}$, a decrease in the $0_{2}$ concentration to $14.0 \%$, an increase in the sodium smoke concentration to its maximum of $13 \mathrm{~g} / \mathrm{m}^{3}$ and low but slightly positive (0.01-0.1 in. $\left.\mathrm{H}_{2} \mathrm{O}\right)$ differential pressure.

The $\mathrm{N}_{2}$ flood was started at 60 SCFM 15.05 minutes after start of sodium spill. Smoke emission from the mockup immediately increased and the differential pressure jumped to 0.3 in. $\mathrm{H}_{2} \mathrm{O}$. The sodium pool continued to increase in temperature unt11 it reached its maximum of $1055^{\circ} \mathrm{F}$ at 25 minutes after the spil1. The $\mathrm{O}_{2}$ concentration decreased somewhat more rapidly during this time than prior to the flood and was $7.8 \%$ at time 25 minutes.

The differential pressure increased erratically to a maximum of 0.7 in $\mathrm{H}_{2} \mathrm{O}$ at time 120 minutes. This is believed caused by partial plugging of leak passages in the mockup structure by deposited smoke particles.. Fluffy powder fell from the vacuum breaker and pressure relief vent periodically.

The mockup atmosphere reached its maximum average temperature of $296^{\circ} \mathrm{F}$ at time 50 minutes. The temperature near the mockup floor was $280^{\circ} \mathrm{F}$ at near the ceiling it was $325^{\circ} \mathrm{F}$ at that time. 
Two hundred and twenty minutes after the spill, the $\mathrm{N}_{2}$ flood was reduced in steps so that a leakage rate curve of leak rate versus DP could be made. Flooding was terminated 236 minutes after the spill, at which time the sodium pool temperature was $350^{\circ} \mathrm{F}$.

Vis bility in the fire room decreased to $\sim 15 \mathrm{ft}$ shortly after $\mathrm{N}_{2}$ flooding started, then cleared up, until at $t=140$ minutes, it was quite clear. At this time the visibility inside the mockup was improving.

After the $\mathrm{N}_{2}$ flood was terminated, the $\mathrm{O}_{2}$ concentration started to increase from $0.02 \%$ to a maximum of $2.7 \%$ about 8 hours after the spill. It then decreased to $\sim 2 \%$ at the same time that the smoke concentration in the mockup atmosphere increased and visibility on the TV monitor decreased. This low grade oxidation continued until $\sim 12 \mathrm{hr}$ after the spill. The sodium pool temperature continued to decrease during the period, until it started to freeze at $13 \mathrm{hr}$.

Twenty-one hours after the spill, when the sodium pool was $150^{\circ} \mathrm{F}$, a low flow of $\mathrm{N}_{2}$ was established to prevent further sodium change prior to sampling. The $\mathrm{O}_{2}$ concentration was $3.6 \%$ at the time.

Forty five hours after the spill, the sodium pool temperature was $85^{\circ} \mathrm{F}$. At this time, operators entered the mockup to sample and take photographs.

A table of chronological events and observations is given in Appendix B.

\section{B. RESULTS DURING FIRE PERIOD}

The instrumentation output during the initial $11-\mathrm{hr}$ period of the fire is plotted in Figure 10. Data for sodium pool temperature, mockup atmosphere temperature, nitrogen flood rate, differential pressure and oxygen concentration are plotted in one figure so that their interrelationship can be displayed. Figure 10 shows that the only immediate effect of the $\mathrm{N}_{2}$ flood was to increase the differential pressure. The $\mathrm{O}_{2}$ concentration continued to decrease until the end of the $\mathrm{N}_{2}$ flooding period, after which it increased slowly. The sodium pool and mockup atmosphere temperatures decreased steadily after they had reached their maxima approximately 15 minutes after the start of $\mathrm{N}_{2}$ flooding. The same data are presented in greater detail in the following sections. 

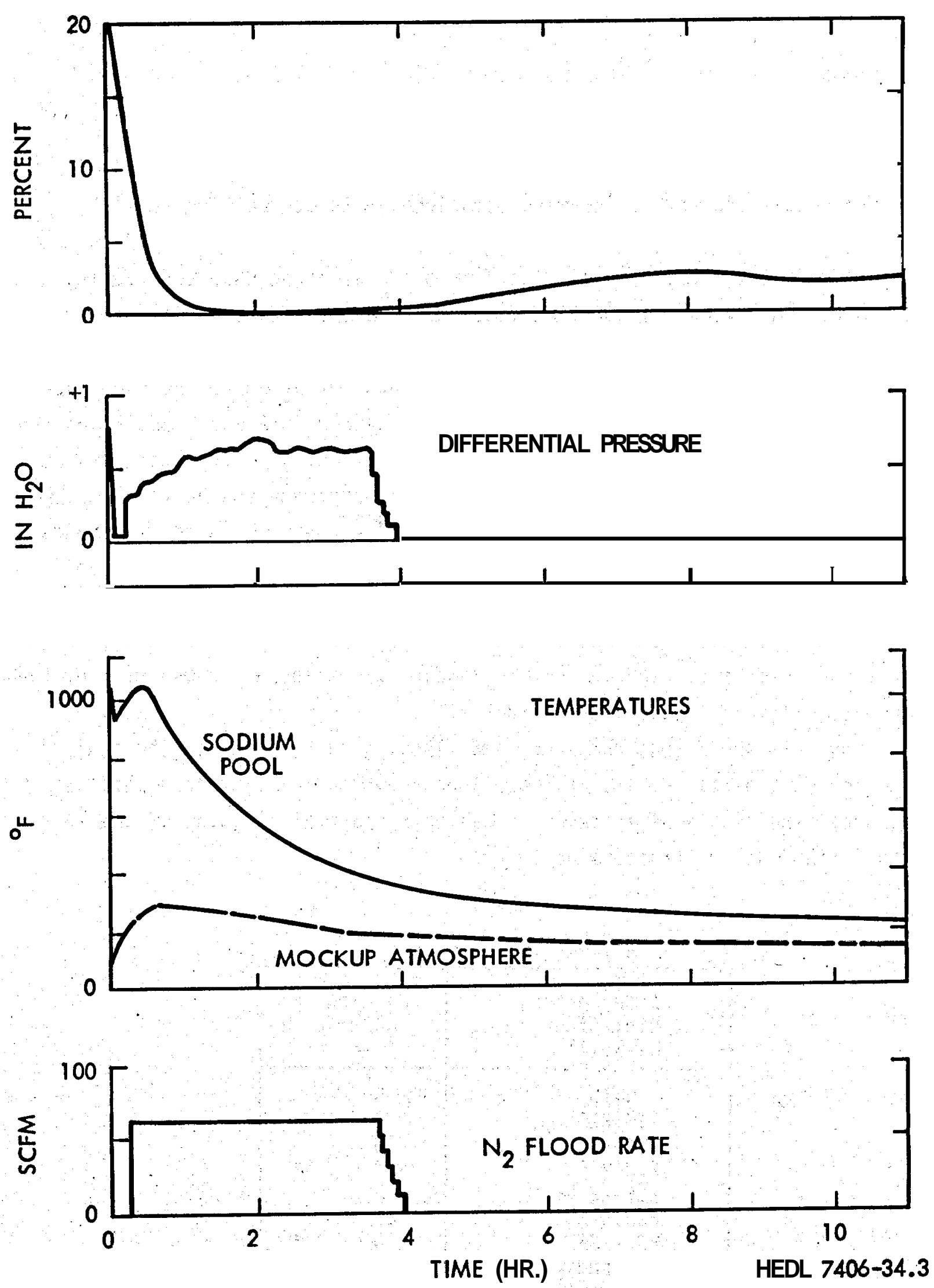

FIGURE 10. Instrument Data Output During Fire Period. 


\section{Nitrogen Flooding System Operation}

The $\mathrm{N}_{2}$ flooding system operation was very stable. The globe valve used for manual control was trimmed occasionally to correct for small changes in the temperature of the nitrogen gas, which varied from 77 to $81.5^{\circ} \mathrm{F}$ during the flood period. The flow of $\mathrm{N}_{2}$ averaged 60.8 SCAM during the 205 minutes of nominal 60 SCFM flooding. Accuracy was $\pm 3.5 \%$. Standard conditions are defined as $60^{\circ} \mathrm{F}$ and 14.7 psia.

A brief leak test of the pipeway mockup was performed during the shutdown of the flooding system. The sodium pool temperature was $\% 360^{\circ} \mathrm{F}$ and the mockup atmosphere temperature was $185^{\circ} \mathrm{F}$ at that time. The leak test was accomplished by reducing the $\mathrm{N}_{2}$ flow in 10 SCFM increments and waiting for about 3 minutes to obtain a steady state differential pressure at each flow rate. The history of the $\mathrm{N}_{2}$ flow is shown in Table II and shown graphically in Figure 11. The leak rate data are discussed in Section 3, below.

The $\mathrm{N}_{2}$ flow totalizer showed that 12,100 SCF were used during the entire flooding'period. 135 gallons of liquid $\mathrm{N}_{2}$ were used, as measured by the liquid level gauge in the storage tank.

Figure 11 shows that the specified flooding rate, based on the analysis given in Section 111. C. 1., was more than adequate to maintain a positive pressure. The excess DP is believed caused by partial plugging of the leak paths in the mockup structure and vents.

\section{TABLE II}

NITROGEN ROOD HISTORY

\begin{tabular}{|l|c|}
\hline $\begin{array}{l}\text { Time Period, } \\
\text { Min. After } \\
\text { Na Spill }\end{array}$ & $\begin{array}{c}\mathrm{N}_{2} \text { Flow } \\
\text { SCFM* }\end{array}$ \\
\hline $0-15$ & 0 \\
$15-220$ & 60.8 \\
$220-223$ & 50 \\
$223-226$ & 40 \\
$226-228.5$ & 30 \\
$228.5-231$ & 20 \\
$231-236$ & 10 \\
$236-$ end of test & $\mathbf{0}$ \\
\hline \multicolumn{2}{|c|}{ * STP = 14.7 psia, $60^{\circ} \mathrm{F}}$. \\
\hline
\end{tabular}






FIGURE 11. Sffect of Nitroget Flooding Rate on Mockup Didperential Pressure 


\section{Sodium Pool Temperature}

The temperatures at four depths near the center of the sodium pool are plotted in Figure 12 for the initial 80 -min. period. The arithmetic average of these four thermocouples plus two thermocouples near the edges of the pool is also plotted. The average pool temperature is plotted for 22 hours in Figure 13. Several observations are noteworthy.

The temperature of the sodium was quenched by $275^{\circ} \mathrm{F}$ (average) during the spill, Delivered at $1100^{\circ} \mathrm{F}$ from the batch tank, it averaged $825^{\circ} \mathrm{F}$ one min. after the spill. This is in fair agreement with the predicted equilibrium temperature of $805^{\circ} \mathrm{F}$, which assumed that the cold spill pipe and catch pan attained the same temperature as the sodium and that heat of reaction was negligible during the spill.

A range in pool temperature of approximately $75^{\circ} \mathrm{F}$ existed for the initial 10 min. after the spill, with the highest temperature registered by the thermocouple nearest the air-sodium interface and the lowest by the TC which contacted the pan bottom. The gradient in the liquid was

$\sim 13^{\circ} \mathrm{F} / \mathrm{in}$. The range had narrowed to $60^{\circ} \mathrm{F}\left(10^{\circ} \mathrm{F} /\right.$ in. $)$ at $15 \mathrm{~min}$; $15^{\circ} \mathrm{F}$ ( $3^{\circ} \mathrm{F} /$ in. $)$ at $60 \mathrm{~min}$.

All sodium temperatures increased steadily during the first 25 minutes. Startup of the nitrogen flood had no immediate effect on the rate of temperature increase of the bulk sodium. The pool reached it s maximum temperature of $1055^{\circ} \mathrm{F}$ ten minutes after the start of $\mathrm{N}_{2}$ flooding.

All thermocouples in the sodium decreased steadily after $25 \mathrm{~min}$. The rate of decrease slowed to only about $3^{\circ} \mathrm{F} / \mathrm{hr}$ near the freezing point, and $5 \mathrm{hr}$. were required to complete the freezing isotherm.

\section{Mockup Gas Temperature}

The temperature of the gas atmosphere directly above the sodium pool is plotted in Figure 14, with elevation as the parameter. The most significant information shown by this figure is that the high temperature associated with the sodium or the sodium-air reaction does not extend more than a few inches above the surface of the pool. The maximum temperature' attained by the thermocouple $7.5 \mathrm{in}$. above the pool surface was only $600^{\circ} \mathrm{F}$. $\rightarrow$ 




FIGURE 12. Sodium Poo remperatures Duritgg Initial 80-minute Period 


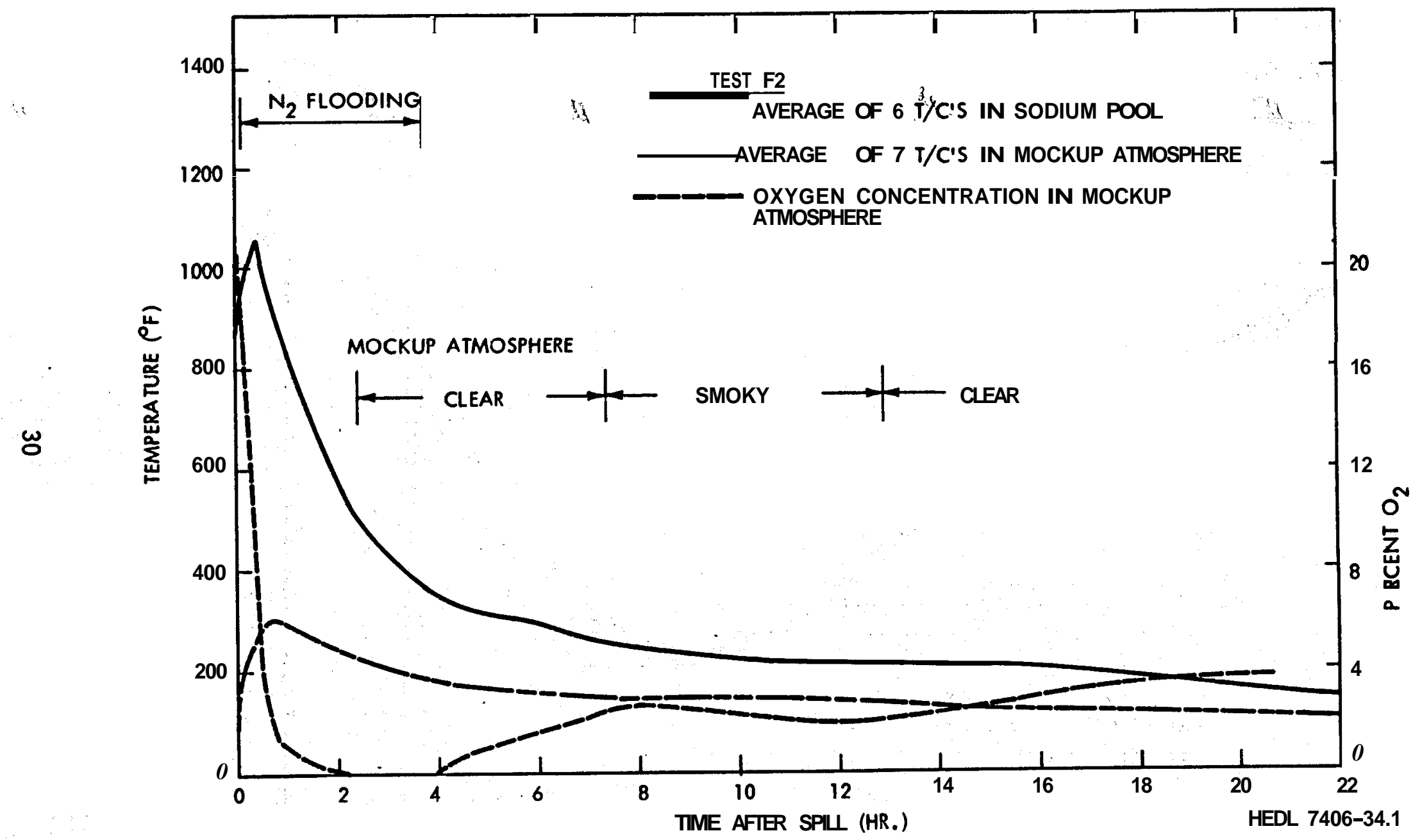

FIGURE 13. Long-Term Temperatures and Oxygen Relationship 


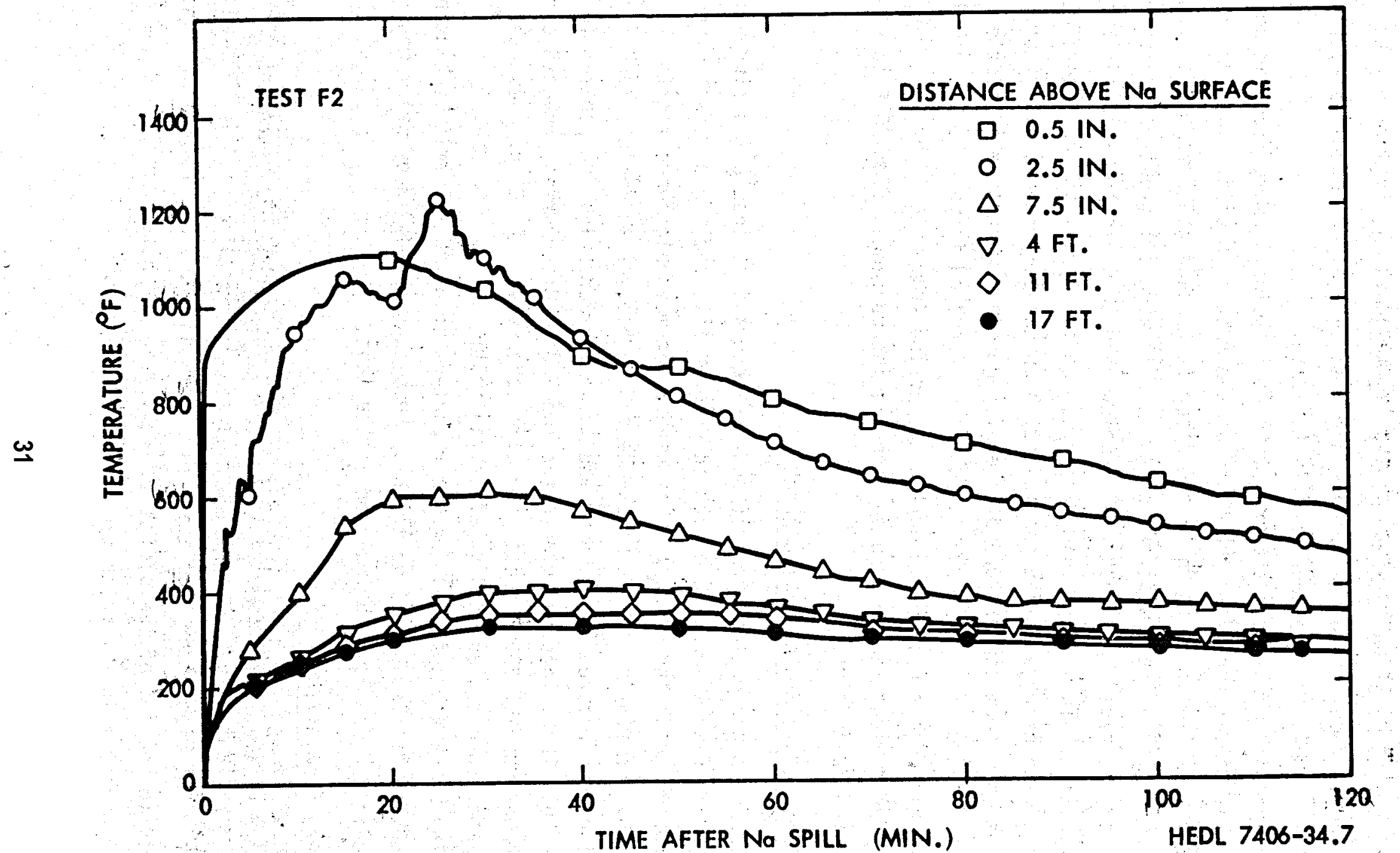

FIGURE 14. Gas Temperatures Above Sodium Pool. 
The maximum temperature recorded by "any thermocouple was $1220^{\circ} \mathrm{F}, 2.5$ in. above the surface. Figure 14 also shows that the temperature at elevations 4 to $17 \mathrm{ft}$ above the pool were nearly the same.

Figure 15 shows the gas temperature at locations remote from'the sodium pool. The temperature near the floor of the mockup reached a maximum of about $270^{\circ} \mathrm{F}$, while at $17 \mathrm{ft}$ above the floor it reached $330^{\circ} \mathrm{F}$ maximum. Temperatures in the extreme west end of the $3.5-\mathrm{ft}$ wide ell (most remote from the fire area) averaged only about $20^{\circ} \mathrm{F}$ cooler than those in the main $10-\mathrm{ft}$ by $15-\mathrm{ft}$ section. This shows that mixing was quite significant and that the effect of the nitrogen flood gas injection on gas temperature was minor.

The long-term temperature of the average gas temperature is plotted to $22 \mathrm{hr}$ in Figure 13. The mockup atmosphere decreased in temperature continuously, although the decrease during the period from 6 to $12 \mathrm{hr}$ was very slow. The ambient temperature outside the mockup ranged from $60^{\circ} \mathrm{F}$ to $86^{\circ} \mathrm{F}$ during the 22-hr period.

\section{Temperature of Insulating Brick}

The burn pan rested directly on three courses of insulating fire-brick, as shown in Figure 7 and described in Chapter 111, Section B. Each course was $2.5 \mathrm{in}$. thick and no mortar was used. Thermocouples were located at 2.5, 5.0, and 7.5-in. depths below the pan bottom, as shown in Appendix A.

The temperatures recorded by the three thermocouples are plotted in Figure 16. TC 3, located between the top and middle courses, reached a maximum temperature of $395^{\circ} \mathrm{F}$ about $2 \mathrm{hr}$ after the spill. At 5 in. deep, the maximum temperature was about $5 \mathrm{hr}$ after the spill.

The brick was analyzed for water content prior to the test by heating to $1650^{\circ} \mathrm{F}$. It lost $0.085 \%$ by weight. Less than one pound of water was contained in the $980 \mathrm{lb}$ of brick used in the test.

\section{Pressure Differential}

The pressure differential (DP) between the mockup gas space and the outer fire room is plotted in Figure 11. A maximum DP of 1.4 in. $\mathrm{H}_{2} \mathrm{O}$ was attained $26.5 \mathrm{sec}$ after initiation of sodium spill. This time corresponded closely to the end of the sodium delivery from the batch tank, as evidenced by the pressure in the batch tank. dropping to zero. 


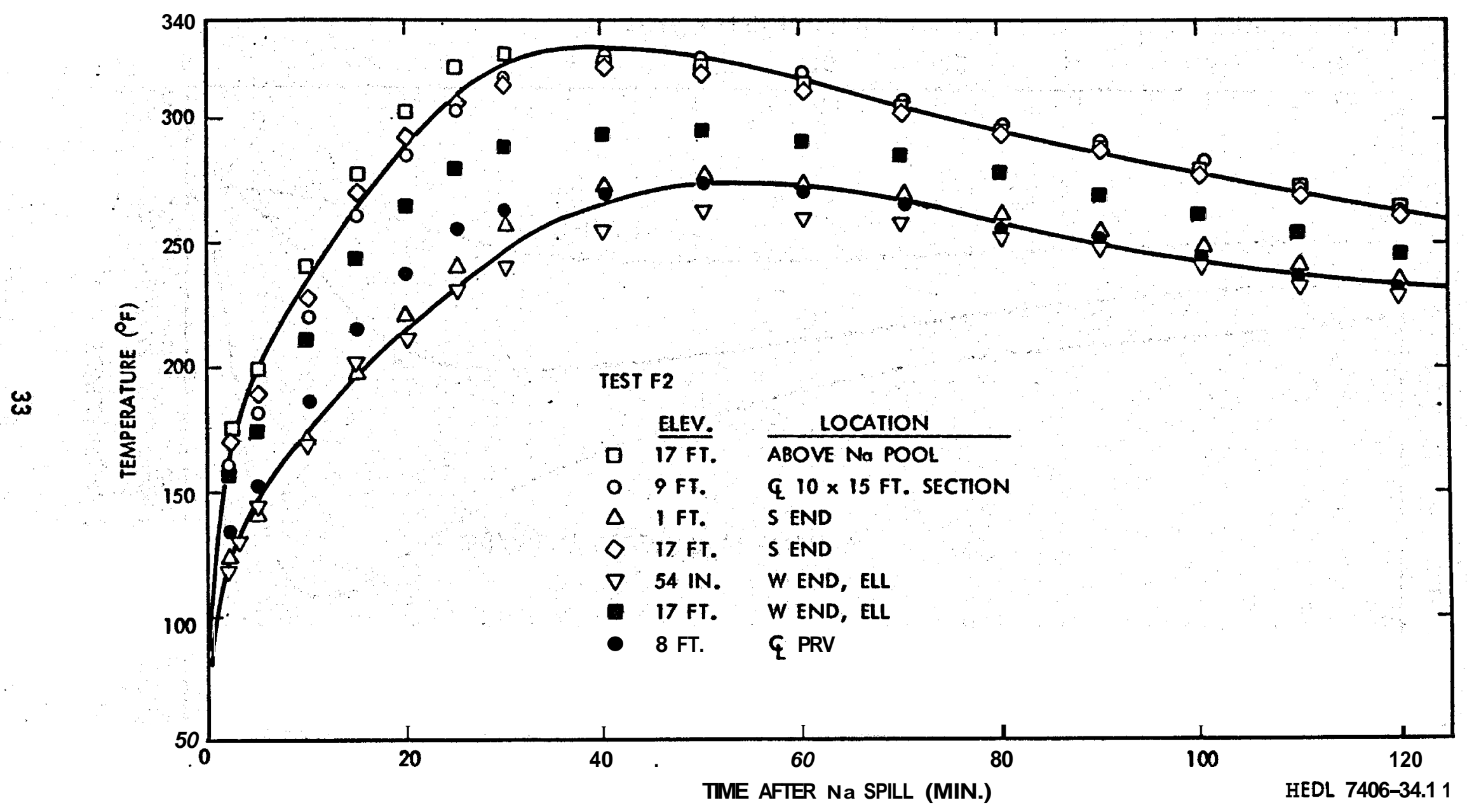

FIGURE 15. Temperature of Mockup Gas Space. 


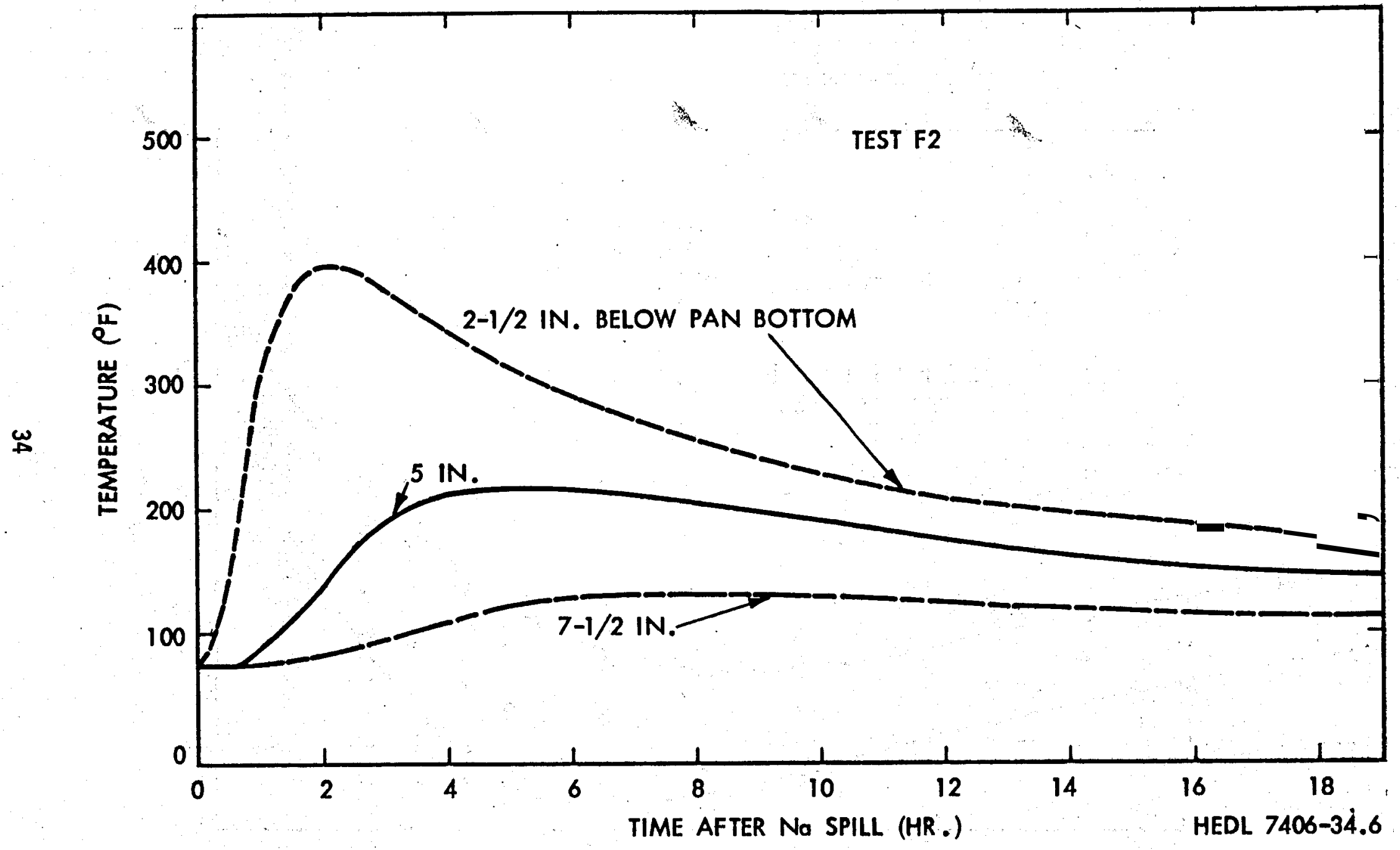

FIGURE 16. Temperature of Insulating Firebrick. 
The bui ldup: of pressure during the nitrogen flooding period is believed to be caused by partial plugging of leak points by deposited smoke particles. The DP increased from 0.3 in. $\mathrm{H}_{2} \mathrm{O}$ immediately after starting the flood to a maximum of 0.7 in. $\mathrm{H}_{2} \mathrm{O}$ at about $2 \mathrm{hr}$. Fluctuations in the DP at times later than $2 \mathrm{hr}$ corresponded to the periodic loss of some of this fluffy powder by blowing loose and falling to the floor, especially from the main leak point in the vacuum breaker.

The "chimney" effect, discussed in Chapter 111, Section C, was believed responsible for causing significant inflow of air during test $F$. In that test, only one pressure transducer was used, so that the chimney effect was not measured directly. In the present test, a second transducer was installed 6 in. above the mockup floor. The first transducer was left at the 14-ft elevation. The difference in DP readings due to the chimney effect can be calculated by Equation (7).

At the time that $\mathrm{N}_{2}$ flooding was started, the average cell gas temperature was $238^{\circ} \mathrm{F}$, the air temperature outside the mockup was $85^{\circ} \mathrm{F}$, and the transducers read +0.03 and -0.01 in. $\mathrm{H}_{2} \mathrm{O}$ for the upper and lower locations, respectively. Taking $\Delta y$ at $13.5 \mathrm{ft}$, Equation (7) predicts $\Delta(D P)$ to be 0.040 in. $\mathrm{H}_{2} \mathrm{O}$, which is in exact agreement with the experimental data. This confirms the validity of Equation (7) for use in predicting cell conditions in actual plant fires. After nitrogen flooding was started, the DP was the same at both locations, indicating that the pressure gradients caused by the $\mathrm{N}_{2}$ jet overshadowed those due to the chimney effect.

\section{Oxygen Concentration}

The concentration of oxygen in the mockup atmosphere during the first hour of the fire is plotted in Figure 17. The data provide several important facts regarding the sodium burning rate, extent of stirring induced by convection, and effect of $\mathrm{N}_{2}$ flooding on sweeping oxygen from the cell atmosphere.

Figure 17 shows that the mockup atmosphere was fairly uniform in oxygen concentration, with samples from three widely different locations giving nearly identical slopes. The sample point in the $3.5-\mathrm{ft}$ ell was directly below the $\mathrm{N}_{2}$ discharge nozzle, which caused its readings to be slightly lower 


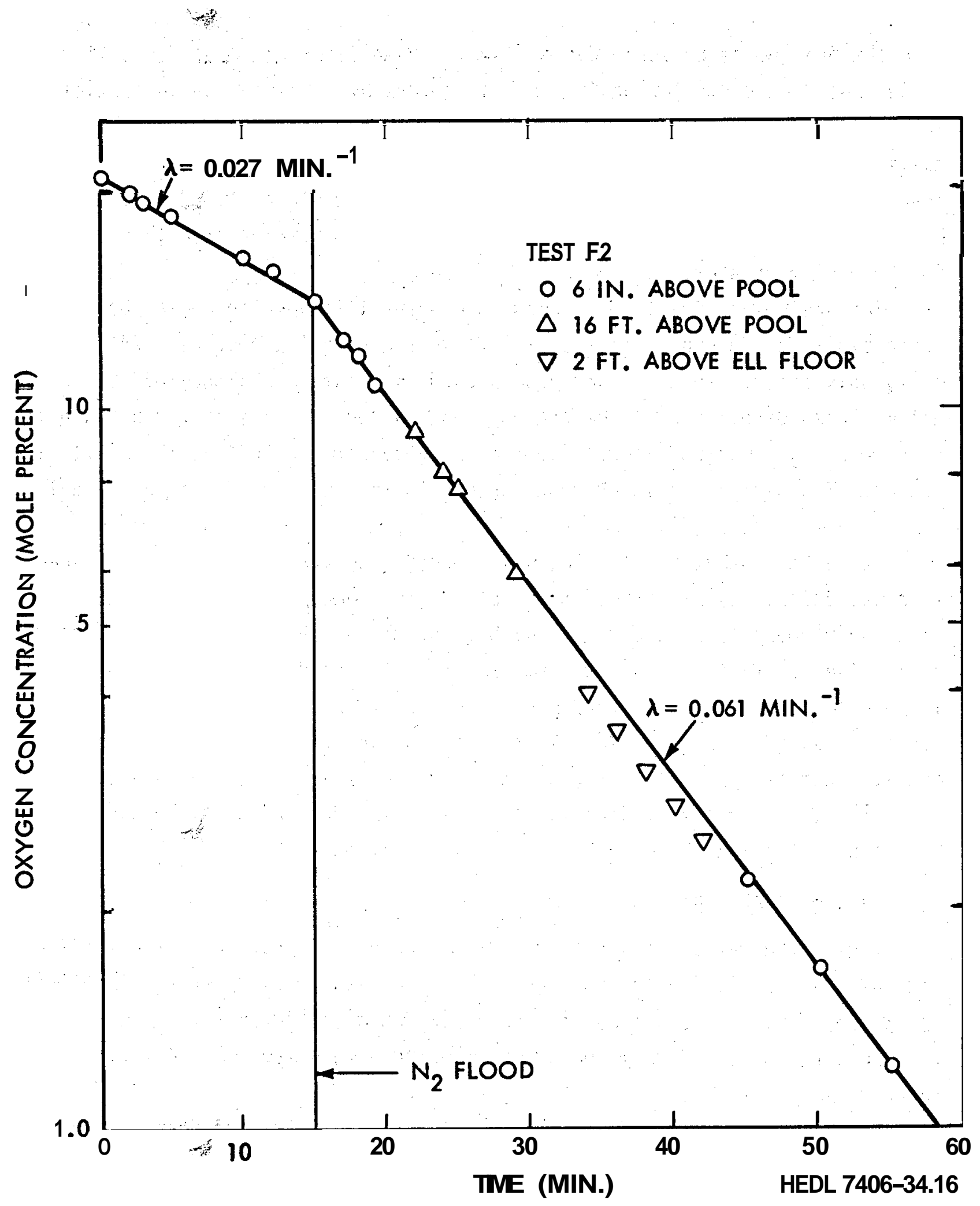

FIGURE 17. Oxygen Concentration In Modkp Atmosphere During The First Hour. 
than the other two points. It is concluded that mixing by natural convection caused sufficient agitation that the mockup atmosphere can be considered well stirred for analytic purposes.

Figure 17 shows that the $0_{2}$ concentration decreased exponentially with time during the initial 15 -minute period before $N_{2}$ flooding was activated. The data can be expressed mathematicaliy by Equation ( 8 ).

$$
c / c_{0}=e^{-\lambda_{b} t} ; t<t_{f}
$$

where:

$$
\begin{aligned}
& \text { C }=\mathrm{O}_{2} \text { concentration at time } \mathbf{t}, \mathcal{*} \\
& \text { co }=\mathrm{O}_{2} \text { concentration at } \mathrm{t}=0 \text {, } \% \\
& \lambda_{b}=0_{2} \text { decay constant due to sodium burning, } \mathrm{min}^{-1} \\
& \mathbf{t}=\text { time after sodium spill, } \mathrm{mfn} \\
& t_{f}=\text { time } N_{2} \text { flooding starts, min after Na spill }
\end{aligned}
$$

The only mechanism for reducing the relative $\mathrm{O}_{2}$ concentration, expressed as mole percent, was the reaction with sodium. The absolute concentration, expressed as moles $\mathrm{O}_{2}$ per unit volume of contained space, was decreased by venting of the vessel due to heatup of the atmosphere within the vessel. Figure 17 shows that the value of $\lambda_{b}$ was $0.027 \mathrm{~min}^{-1}$. A mass balance of oxygen in the mockup atmosphere gives:

$$
c / c_{0}=\exp \left(-\frac{\mathrm{k}_{\mathrm{g}} \mathrm{At}}{\mathrm{y}}\right)
$$

where:

$\mathbf{k}_{\mathbf{g}}=$ mass transfer coefficient, $\mathrm{ft} / \mathrm{min}$

$A=$ sodium-gas interfacial area, $\mathrm{ft}^{2}$

$v=$ volume of enclosed gas space, $\mathrm{ft}^{3}$.

Thus, the $\mathrm{O}_{2}$ decay constant can be expressed as:

$$
\lambda_{b}=\frac{k_{g} A}{V}
$$

Solving Equation (10) for the conditions of test Fa aives a value nf $2.9 \mathrm{ft} / \mathrm{min}$ for $\mathrm{k}_{\mathrm{g}}$. The rate of $\mathrm{O}_{2}$ consumftion due to burning is:

$$
r_{o x}=k_{g} A C
$$

where $r_{o x}$ is expressed in $\mathbf{f t}^{3} \mathbf{O}_{2}$ /min at cell atmosphere, temperature and pressure conditions. In test $\mathbf{F} 2$ at time zero, $r_{\text {ox }}=19.2 \mathrm{ft}^{3} 0_{2} / \mathrm{min}$ at $100^{\circ} \mathrm{F}$ or 16.9 SCFM. 
Post-test chemical analysis of the pool residue showed that $\mathrm{Na}_{2} \mathrm{O}$ was the major reaction product.

$$
4 \mathrm{Na}+\mathrm{O}_{2} \longrightarrow 2 \mathrm{Na}_{2} \mathrm{O}
$$

Thus, 4 moles of sodium were reacted per mole of $\mathrm{O}_{2}$, and the burning rate at time zero was $8.2 \mathrm{lb} \mathrm{Na} / \mathrm{hr} \mathrm{ft}^{2}$. At 15 minutes after the spill, the

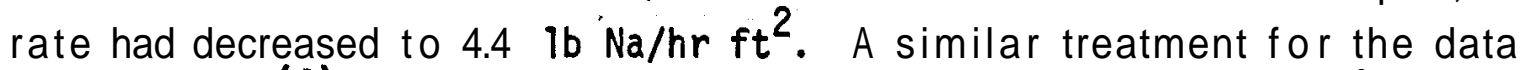

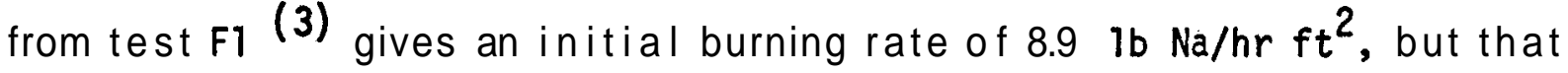
figure is probably high because some of the $\mathrm{O}_{2}$ was being consumed by reaction with $\mathrm{H}_{2}$. The $\mathrm{H}_{2}$ was generated by reaction of sodium with water in the concrete burn pan in test $\mathrm{Fl} . \mathrm{Nb} \mathrm{H}_{2}$ was generated in the present test.

Figure 17 shows that the exponental decay constant increased significantly at the time that $\mathrm{N}_{2}$ flooding was started. This is explained by the sweeping effect of the nitrogen gas, which for an isothermal stirred vessel is:

$$
\lambda_{s}=\frac{F}{V}
$$

where: $\quad \lambda_{s}=0_{2}$ decay constant due to sweep effect, $\min ^{-1}$

$\mathrm{F}=$ flow rate of gas from vessel, $\mathrm{ft}^{3} \%$ min at cell conditions of T,P

For test $\mathrm{F}_{2}, \mathrm{~F}$ was the $\mathrm{N}_{2}$ flood rate adjusted to cell temperature condition, om $90 \mathrm{ft}^{3} /$ min during the first hour of $\mathrm{N}_{2}$ flooding. This gives a predicted value of $0.027 \mathrm{~min}^{-1}$. The total decay was the sum of sweep effect and sodium burning:

$$
\lambda_{T}=\lambda_{S}+\lambda_{b} .
$$

Using the data of Figure $17 \mathrm{i} n$ Equation (14) gives an experimental value for $\lambda_{s}$ of $0.034 \mathrm{~min}^{-1}, 26 \%$ higher than predicted by Equation (13). This is considered to be a reasonable confirmation of Equation (13).

The sodium burning rate, $r_{\mathrm{Na}}$, can be expressed by Equations (15a) and (15b) for the pre-flood and flooding periods, respectively..

$$
\begin{aligned}
& r_{\mathrm{Na}}=\frac{315 \mathrm{P}}{T} e-\frac{2.9 \mathrm{At}}{V} ; 0<t<t_{f} \\
& r_{\mathrm{Na}}=\frac{315 \mathrm{P}}{T} e-\frac{2.9 \mathrm{At+}+\mathrm{F}\left(t-t_{f}\right)}{V} ; t>t_{f}
\end{aligned}
$$


where: $\quad r_{\mathrm{Na}}=$ sodium burning rate, $1 \mathrm{~b} / \mathrm{hr} \mathrm{ft}^{2}$

$$
\begin{aligned}
& \mathrm{P} \quad=\text { absolute pressure, psia } \\
& \mathrm{T}=\text { absolute temperature of cell gas, }{ }^{\mathbf{O}_{R}}
\end{aligned}
$$

The $\mathbf{O}_{2}$ concentration at longer 'times is shown in Figure 18. The $\mathbf{0}_{2}$ concentration, which had decreased to $0.02 \%$ by the end of the $\mathrm{N}_{2}$ flooding period, increased rapidly as soon as $\mathrm{N}_{2}$ flooding was stopped. Four hours after $\mathrm{N}_{2}$ flood termination it was $2.7 \%$. At this time, it started to decrease slowly, indicating that a slow reaction of oxygen with sodium was occurring. This decline lasted $4 \mathrm{hr}$ and coincided with the period that smoke was seen on the TV monitoring the cell interior and also being emitted from the vacuum breaker leak point. At times later than $12 \mathrm{hr}$ the oxygen concentration increased steadily, until at $21 \mathrm{hr}$ it was $3.65 \%$.

Table III shows the results of mass spectometric analyses of grab samples taken from the mockup atmosphere at various times. The $\mathrm{O}_{2}$ analysis agreed very closely with the on-line Beckman Analyzer results plotted in Figures 17 and 18. Table III shows that the nitrogen flood gas had $<0.01 \%$ oxygen and that no $\mathrm{H}_{2}$ was released during the test.

\section{Sodium Oxide Aerosol}

The aerosol concentration in the mockup atmosphere, the fire room and in the ventilation system is plotted in Figure 19. The maximum concentration was $13 \mathrm{~g} / \mathrm{m}^{3}$ (STP) as $\mathrm{Na}$ Analysis for chemical composition of the aerosol was not attempted. The concentration in the mockup atmosphere decreased after the initial $20 \mathrm{~min}$ period, with a half life of approximately $20 \mathrm{~min}$. This compares with a 42 min half life measured in test Fl where gravitational settling was problably the chief removal mechanism. The more rapid removal during test F2 was due to the sweep effect of the $\mathrm{N}_{2}$ flood. The discontinuity in the curve of the mockup atmosphere aerosol concentration corresponds to the visual observations by TV monitor of the mockup becoming smoky during the period from 7 to $13 \mathrm{hrs}$ after the' spill. However, the aerosol concentration 'only attained a level of a few hundred $\mathrm{mg} / \mathrm{m}^{3}$ during this low-grade combustion event. 


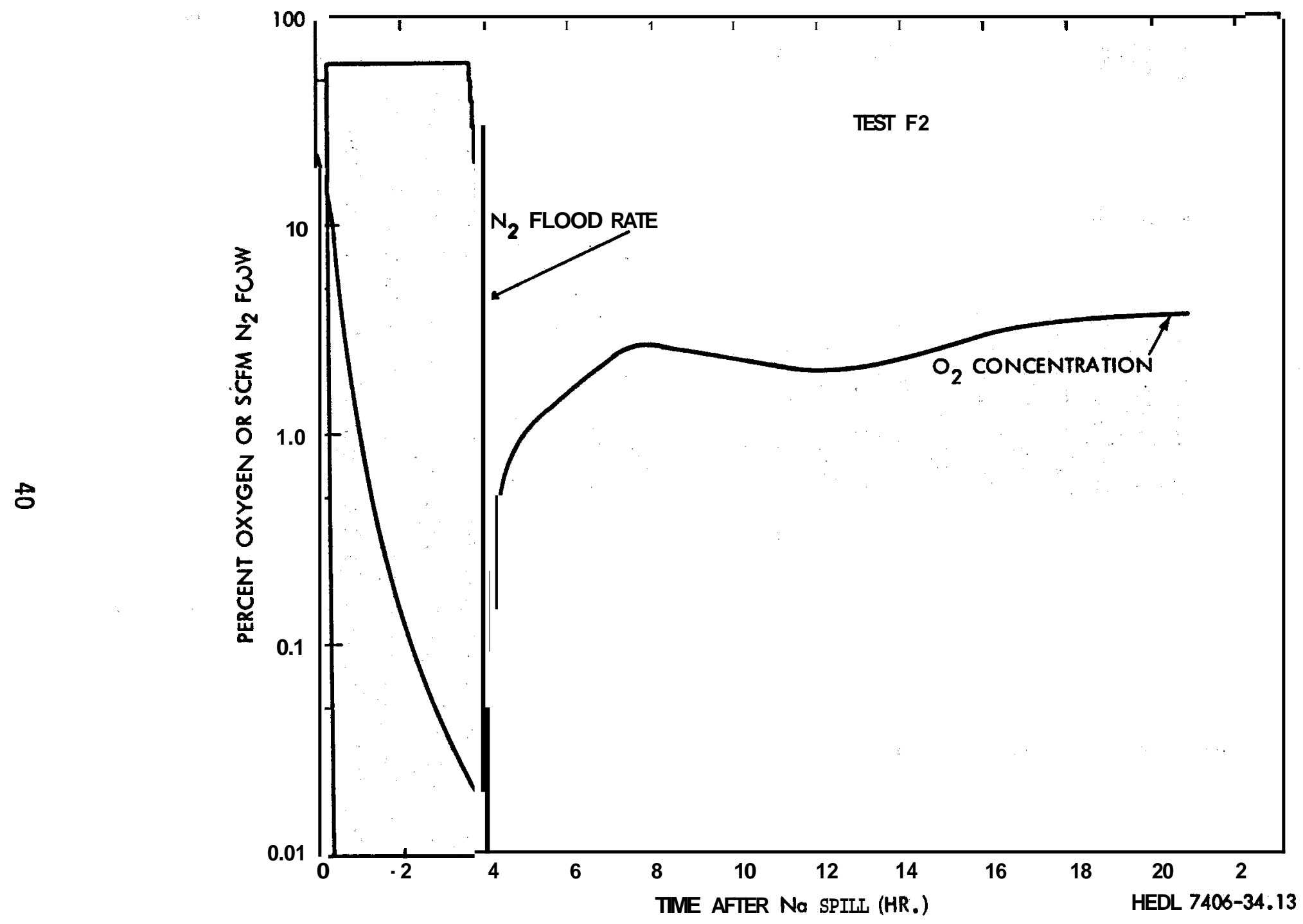

FIGURE 18. Oxygen Concentration In Mockup Atmosphere. 


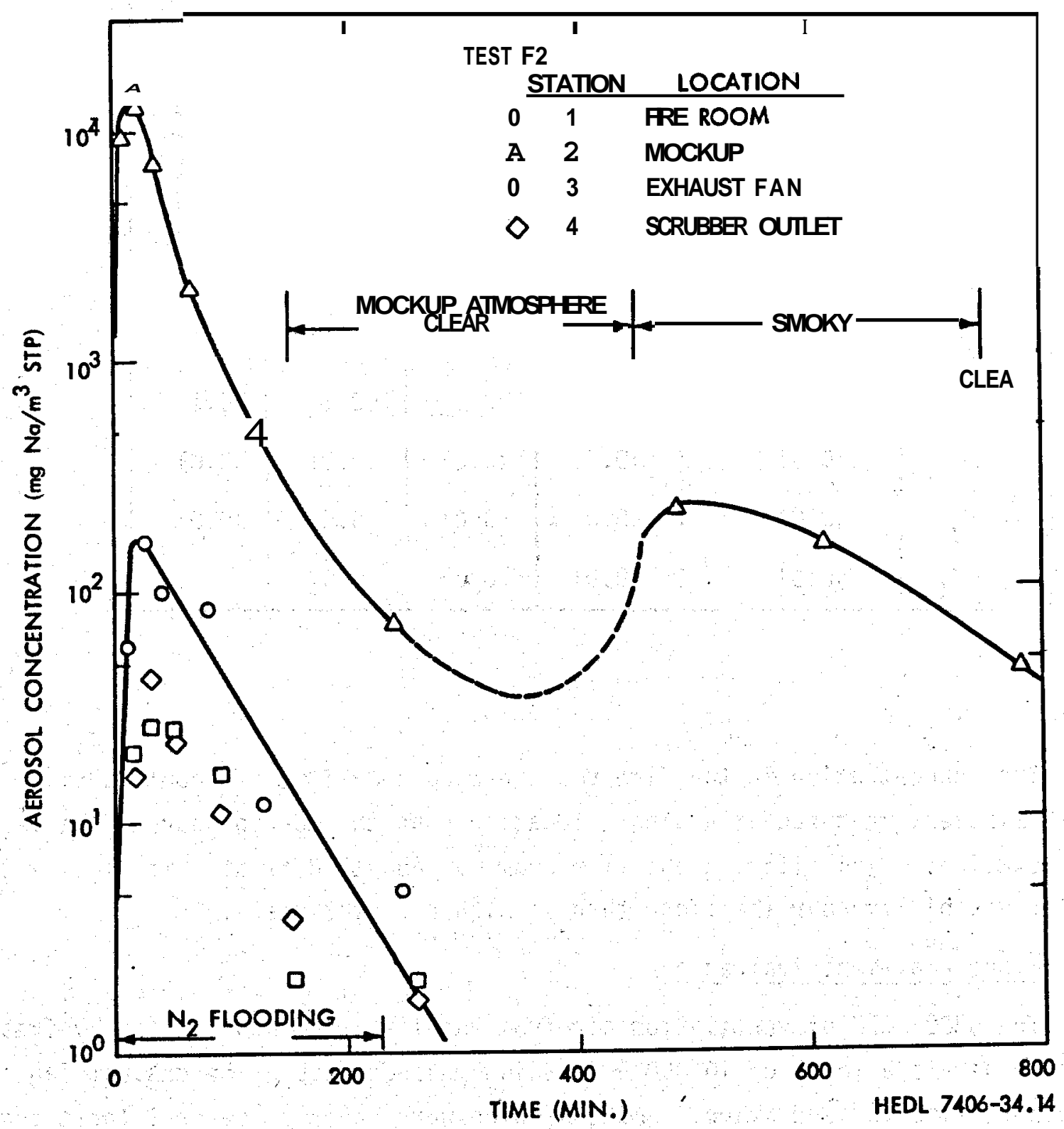

FIGURE 19. Sodium Oxide Aerosol Concentration. 
TABLE III

MASS SPECTROMEIER ANALYSIS OF MOCKUP ATMOSPFERE

\begin{tabular}{|c|c|c|c|c|c|}
\hline & \multicolumn{5}{|c|}{ Mole \% } \\
\hline & Flood $^{N_{2}}$ Gas & $t=12 \min$ & $t=40$ & $t=120$ & $t=240$ \\
\hline $\mathrm{O}_{2}$ & $<0.01$ & 15.7 & 2.86 & 0.13 & 0.06 \\
\hline$N_{2}$ & $>99.9$ & 82.6 & 96.1 & 98.8 & 98.7 \\
\hline $\mathrm{Ar}$ & $<0.01$ & 1.54 & 0.99 & 1.08 & 1.20 \\
\hline $\mathrm{CO}_{2}$ & $<0.01$ & 0.12 & 0.03 & $<0.01$ & $<0.01$ \\
\hline $\mathrm{CO}$ & $<0.01$ & $<0.1$ & $<0.1$ & $<0.1$ & $<0.1$ \\
\hline $\mathrm{He}$ & $<0.01$ & $<0.01$ & $<0.01$ & $<0.01$ & $<0.01$ \\
\hline $\mathrm{H}_{2}$ & $<0.01$ & $<0.01$ & $<0.01$ & $<0.01$ & $<0.01$ \\
\hline $\mathrm{CH}_{4}$ & $<0.01$ & $<0.01$ & $<0.01$ & $<0.01$ & $<0.01$ \\
\hline
\end{tabular}

The concentration in the fire room reached a maximum of about $200 \mathrm{mg} / \mathrm{m}^{3}$ at 20 minutes, measured at a single location near the mockup door at the 9 $\mathrm{ft}$ elevation. Visibility in the fire room was about $10 \mathrm{ft}$ at this time, with better visibility near the floor than at higher elevations.

\section{Smoke Abatement Evaluation}

The 5000 SCFM of ventilation a ir from the fire room was diluted by fresh outside air to a total of 10,000 SCFM which passed through the exhaust fan, scrubber, filters, and stack. Smoke samples were taken at several locations in an attempt to evaluate the effectiveness of the smoke abatement system.

The scrubber water picked up $570 \mathrm{~g}$ of sodium. Only $3.8 \mathrm{~g}$ were released to the stack. Assuming a 99\%efficiency for the HEPA filters, the scrubber averaged $60 \%$ overall efficiency. 
"The concentration in the stack during the first hour after the sodium spill (the period of maximum concentration) averaged $0.13 \mathrm{mg} / \mathrm{m}^{3}$. Atmospheric diffusion diluted this. to approximately $2 \times 10^{-5} \mathrm{mg} / \mathrm{m}^{3}$ at the point of maximum downwind ground level concentration. This is five orders of magnitude below the guideline (5) for occupational breathing.

\section{POST TEST EXAMINATION}

\section{General}

Twenty one 'hours after the spill, injection of nitrogen into the mockup was started at a low rate to prevent entry of oxygen and moisture prior to sampling. Aerosol fallout samples were taken from the fire room floor. At 43 hours, ventilation air at about 1000 CFM was drawn through the mockup and operators entered for taking photographs and samples for chemical analysis,. The temperatures of the sodium pool and mockup atmosphere were $85^{\circ} \mathrm{F}$ and $75^{\circ} \mathrm{F}$, respectively.

Figure 20 shows a view of the mockup and residual sodium pool at the time the mockup door was removed. Some observations were:

- The general surface level was approximately that of the orignal sodium level, but oxide had piled in the central area within and surrounding the splash guard.

- The surface of the pool had a metallic luster.

- No evidence was seen that sodium had splashed out of the pan.

- Oxide had wet the pan walls only about $4 \mathrm{in.}$ above the main level, leaving about 3 in. of bare metal wall at the top edges.

- Oxide had climbed over the edge of the burn pan where a painted steel panel ( 12 in. $\times 12$ in.) leaned against the side and where an insulating brick was immersed.

- The vertical walls of the burn pan were not noticeably warped. (Subsequent examination showed that the pan bottom had warped $\sim 1$ in. up in the center, 21 in. down at each end).

- The mockup floor was covered uniformly with a 3/16-in. deep layer of fluffy white powder which appeared dry at the time the door was opened but picked up moisture with time, The mockup walls had considerably less deposit. 


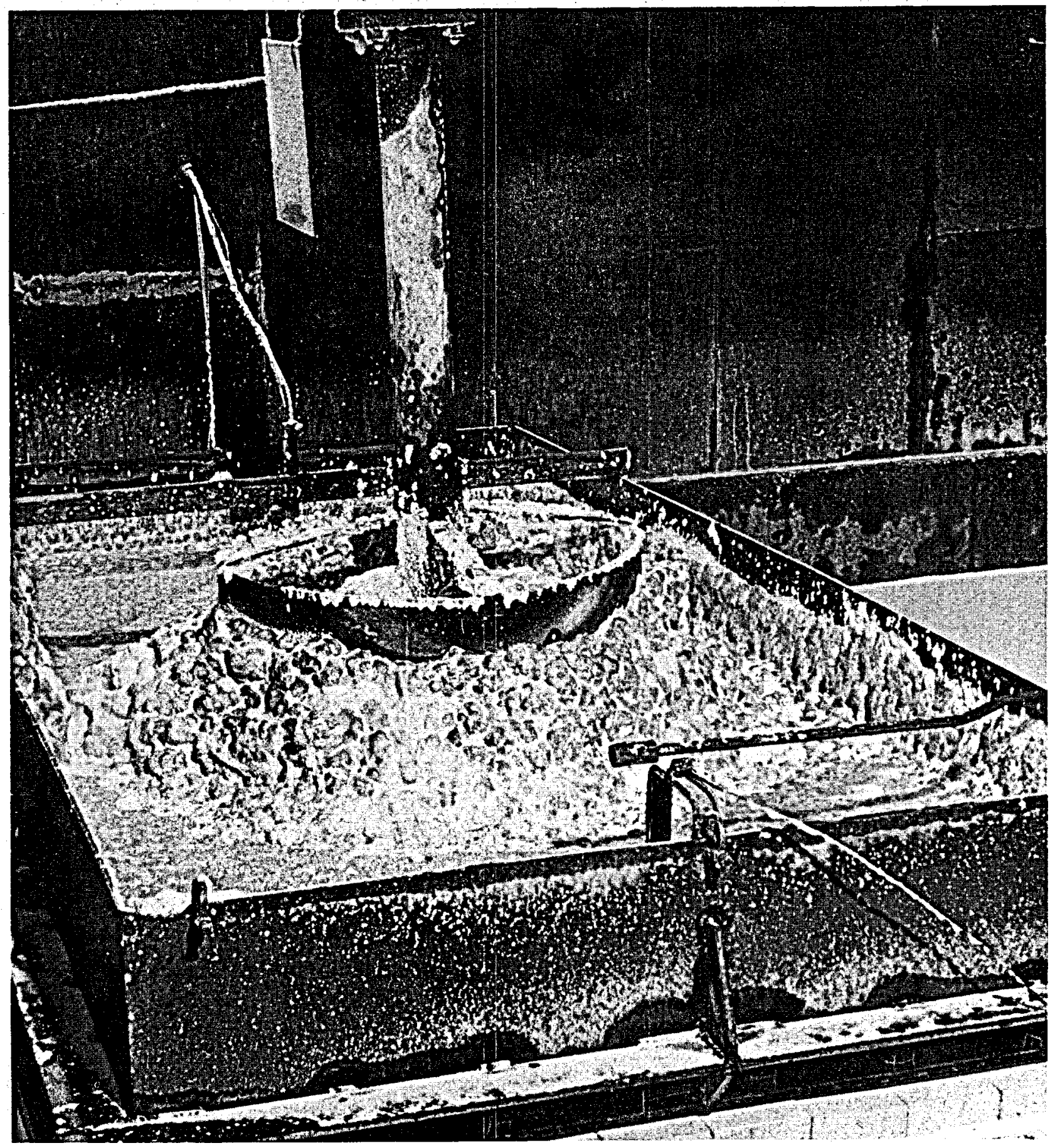

73 HO 233-4

FIGURE 20. View of Burn Pan with Sodium Residue 


\section{Sodium Residue}

Figure 21 illustrates that the main surface level of the residue was about 7-1/2 in. below the top edge of the pan. The frozen pool was thus about $4.5 \mathrm{in}$. deep. The $770 \mathrm{lb}$ of sodium-spilled would have frozen to a pool measuring 5.3 in. deep if none had oxidized. Figure 21 shows that the thermocouples which initially had been in a ir close to the sodium surface were covered by oxide. The point in time at which they ceased, to represent true gas temperature is not known. Approximately 3 to 4 in. of unwetted burn pan wall remained above the sodium oxide.

Core samples were taken at six locations. Figure 22 shows a core sample being taken. The samplers were 5/8-in. tubing sharpened to cut and take a core from top to bottom, including the crust. About $15 \mathrm{~g}$ of sample was obtained by each sampler and these were analyzed for sodium metal, oxygen, and peroxide. The samples averaged $91.5 \%$ metallic sodium; $8.5 \% \mathrm{Na}_{2} \mathrm{O} . \quad \mathrm{Nb} \mathrm{Na}_{2} \mathrm{O}_{2}$ was found in these samples.

The oxide that was heaped around the spash guard was sampled and found to be about $60 \%$ metallic sodium, with the balance $\mathrm{Na}_{2} \mathrm{O}$ and no $\mathrm{Na}_{2} \mathrm{O}_{8}$. The material on the floor averaged $43 \% \mathrm{Na}_{2} \mathrm{O}, 33 \% \mathrm{Na}_{2} \mathrm{O}_{2}, 4 \% \mathrm{Na}_{2} \mathrm{CO}_{3}$, and $20 \%$ water by weight.

A sodium mass balance is presented in Table $\mathrm{N}$ and a summary of chemical forms in Table $V$. Approximately $670 \mathrm{lb}$ of sodium remained in the metallic form. This represents about $87 \%$ of the mass of sodium spilled. About $100 \mathrm{lb}$ had reacted to various chemical forms, chiefly to $\mathrm{Na}_{2} \mathrm{O}$. The material that had settled on the floor of the fire room was recovered from $4 \mathrm{f} \mathrm{t}^{2}$ areas and found to average $230 \mathrm{mg} / \mathrm{ft}^{2}$ as $\mathrm{Na}$. Chemically, it averaged $31 \% \mathrm{Na}$.

The surface material in the burn pan was pyrophoric and ignited when disturbed. However, the heat release was not sufficient to maintain combustion. The crust contained a high percentage of metallic sodium as small particles dispersed among the oxide. It is hypothesized that when air was admitted to the small particles of sodium by disturbing the crust they ignited, but the reaction was self-limiting because of the dispersed state. Figure 22 shows smoke issuing from an area disturbed by sampling. 


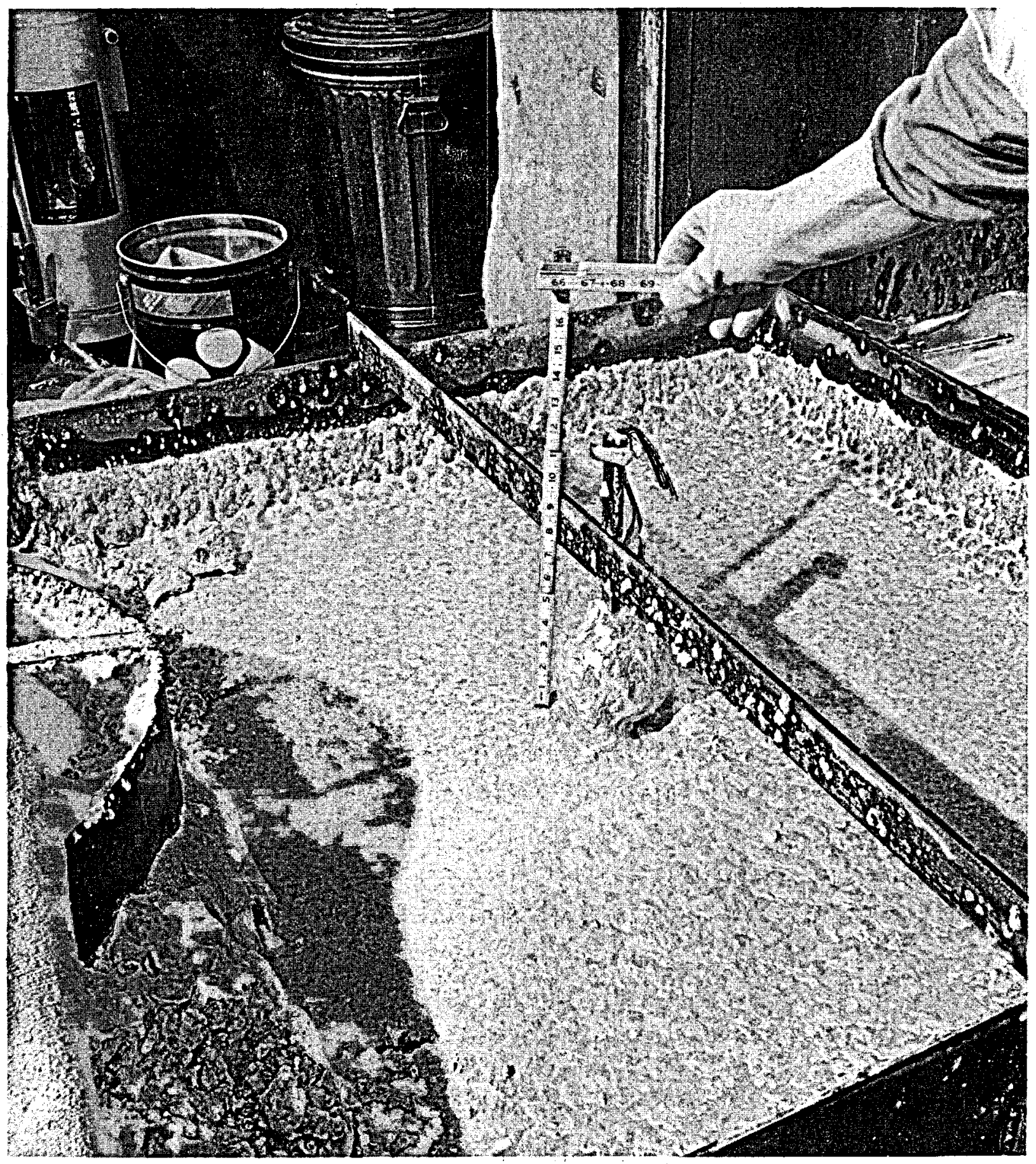

73 HO 234-14

FIGURE 21. Closeup View of Oxide Crust 


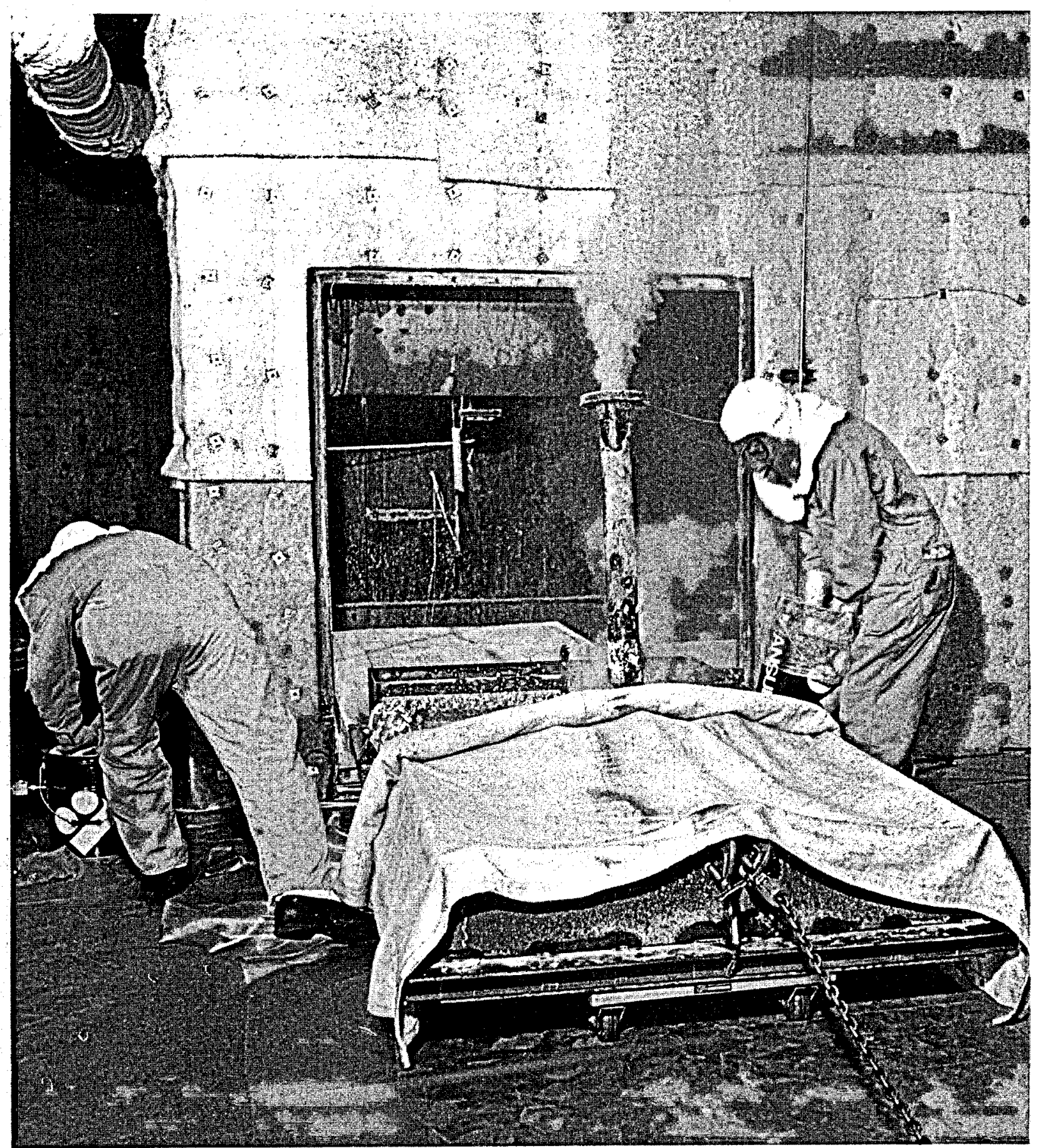

73 HO 234-3

FIGURE 22. Ignition of Sodium Residue Crust During Sampling 
TABLE IV

\begin{tabular}{|c|c|c|c|c|c|c|c|c|}
\hline \multirow[b]{2}{*}{$\begin{array}{l}\text { Residue } \\
\text { Description }\end{array}$} & \multirow[b]{2}{*}{ Total(10) } & \multirow[b]{2}{*}{ Na Metal(10) } & \multirow[b]{2}{*}{$\mathrm{Ha}_{2} \mathrm{O}(\mathrm{b})$} & \multirow[b]{2}{*}{$\mathrm{Na}_{2} \mathrm{O}_{2}(\mathrm{lb})$} & \multirow[b]{2}{*}{$\mathrm{Ha}_{2} \mathrm{CO}_{3}(\mathrm{lb})$} & \multirow[b]{2}{*}{$\mathrm{H}_{2} \mathrm{O}(\mathrm{Ib})$} & \multicolumn{2}{|c|}{ Total $\mathrm{Na}$} \\
\hline & & & & & & & $\mathrm{Ib}$ & 8 \\
\hline Solid Residue in Pan & 665 & 608 & 57 & 0 & 0 & 0 & 649 & 84.3 \\
\hline $\begin{array}{l}\text { Mtl. Piled Around Splash } \\
\text { Guard }\end{array}$ & 100 & 60 & 40 & 0 & 0 & 0 & 90 & 11.7 \\
\hline $\begin{array}{l}\text { Mtl on Hockup Walls \& } \\
\text { Floor }\end{array}$ & 50 & $\hat{\mathbf{u}}$ & 21 & 11 & 2 & 10 & 27 & 3.5 \\
\hline $\begin{array}{l}\text { Oxide Escaping } \\
\text { Mockup }\end{array}$ & 5 & 0 & 5 & 0 & 0 & 0 & 4 & 0.5 \\
\hline TOTRL & 820 & 668 & 123 & 17 & 2 & 10 & 770 & 100.0 \\
\hline
\end{tabular}

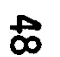

TABLE V

SUMMARY OF CHEMICAL FORMS

\begin{tabular}{|c|c|c|c|c|}
\hline \multirow[b]{2}{*}{ Chemical Form } & \multicolumn{2}{|c|}{ Total } & \multicolumn{2}{|c|}{$\begin{array}{c}\text { Equl valent as } \\
\mathrm{N}\end{array}$} \\
\hline & 16 & \% & $1 \mathrm{~b}$ & $\%$ \\
\hline Hetallic Na & 668 & 81.5 & 668 & 86.8 \\
\hline $\mathrm{H}_{2}{ }_{2} \mathrm{O}$ & 123 & 15.0 & 91 & 11.8 \\
\hline $\mathrm{Na}_{2} \mathrm{O}_{2}$ & 17 & 2.0 & 10 & 1.3 \\
\hline $\mathrm{Na}_{2} \mathrm{CO}_{3}$ & 2 & 0.2 & 1 & 0.1 \\
\hline $\mathrm{H}_{2} \mathrm{O}$ & 10 & 1.3 & 0 & 0 \\
\hline TOTAL & 820 & 100.0 & 770 & 100.0 \\
\hline
\end{tabular}




\section{Test Cell Leak Rate}

The pipe way mockup was undamaged by the fire. Its leak rate was measured before the cleanup and sampling operations and plotted as a function of DP in Figure 23. The leak rates measured prior to the fire and during the fire (at $\mathbf{t}=220 \mathrm{~min}$ ) are also plotted.

The plugging effect of deposited smoke particles is clearly illustrated by the increased DP caused for the same leak rate. The DP was approximately eight times as high during and after the test as before the test.

The mockup was cleared by shoveling and rinsing with water. Figure 24 shows the white, fluffy material being shoveled into buckets.

\section{REFERENCES}

1. R. K. Hilliard, P. E. McPherson and J. M. Yatabe, "Sodium Fire Protection by Space Isolation With Inert Gas Flooding," in Proceedings of the ANS Topical Meeting of Fast Reactor Safety, USABC-CONF 740401, Beverly Hills, California, April 1-4, 1974.

2. R. K. Hilliard, "IAEA-IWGFR Meeting on Sodium Combustion and Its Extinguishment," Nuclear Safety, Vol. 15, No. 2, p. 146. March-April, 1974.

3. R. K. Hilliard and J. M. Yatabe, "FFTF Secondary Sodium Fire Protection System Test F1, "HEDL-TME 73-48, Hanford Engineering Development Laboratory, Richland, Washington, April, 1973.

4. P. Beiriger, et al., "SOFIRE II User Report," AI-AEC-13055, Atomics International, Canoga Park, California, March 30, 1973.

5. "Threshold Limit Values of Airborne Contaminants and Intended Changes," adopted by the American Conference of Governmental Industrial Hygienists, Cincinnati, Ohio, 1970.

\section{ACKNOMHDGEMENIS}

Many individuals contributed to the successful performance of this test. The authors especially wish to acknowledge the help in planning provided by J. M. Yatabe of HEDL EDL, P. E. McPherson of HEDL Engiheering and R. Allen of Bechtel, and the supervision of operations by C. E. Llnderoth. R. F. Keough performed the chemical analyses of the sodium residue. R. E. Sadier, W. N. Romsos, and R. E. Menard had major responsibilities for test preparation, performance and cleanup operations. 


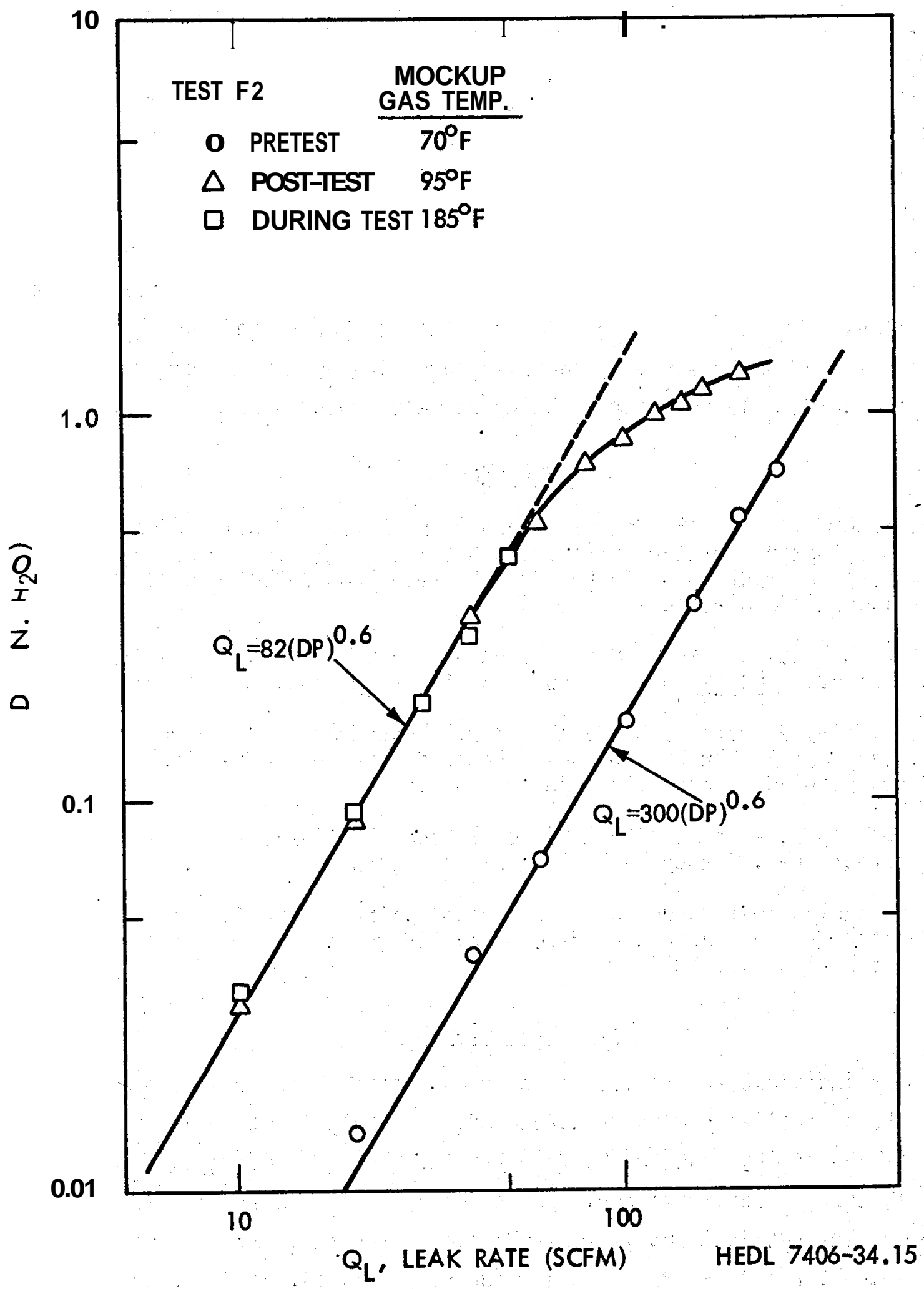

FIGURE 23. Mockup Leak Rate. 


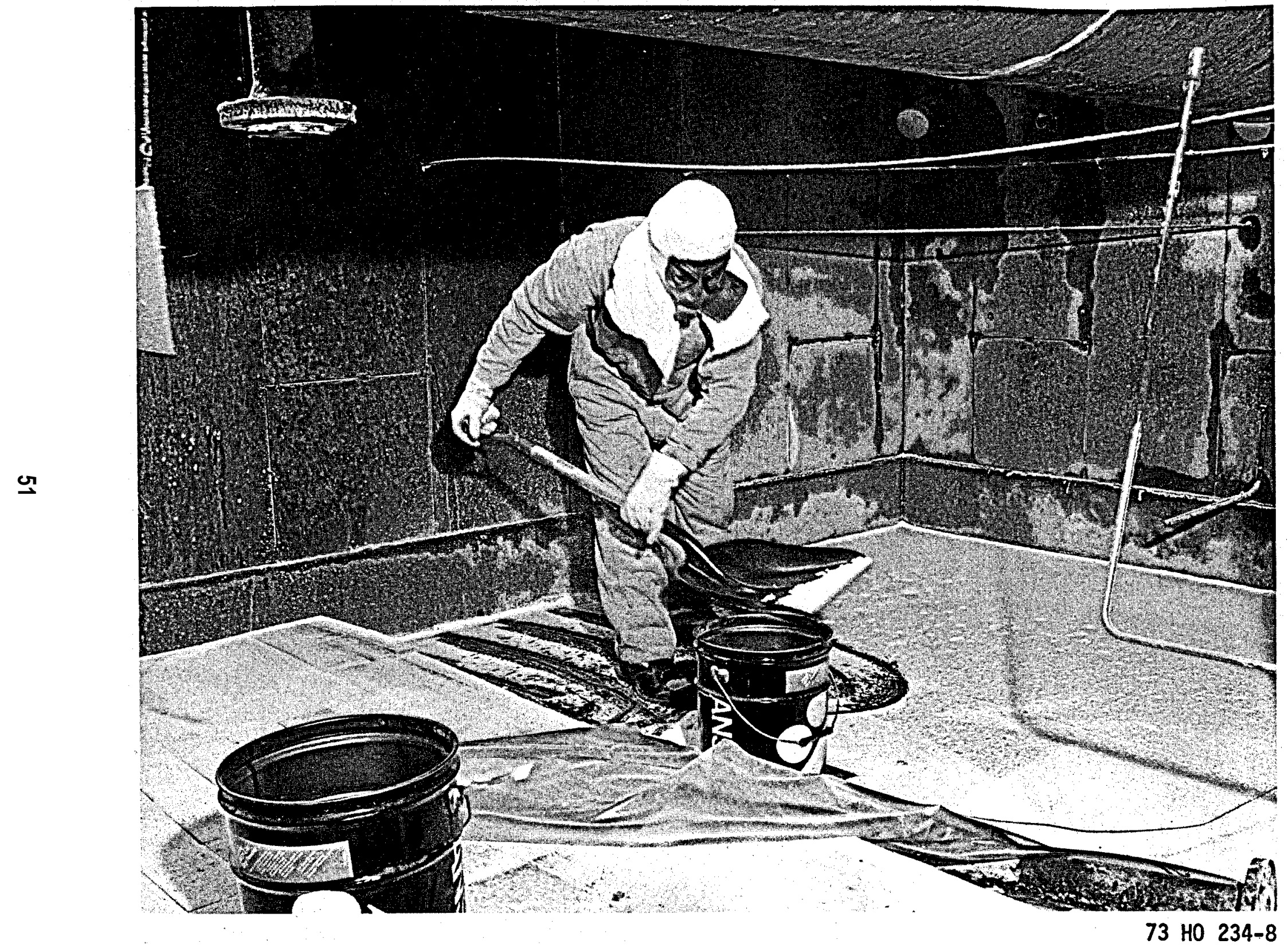

FIGURE 24. Mockup Floor Cleanup Operations 
APPENDIX A

INSTRUMENT SENSOR LOCATIONS

Table A-1 Thermocouple locations

Table A-2 . Gas Sample Point Locations

Table A-3 Aerosol Sample Point Locations

Table A-4 , Pressure Sensor Locations

Figure A-1 Thermocouple Locations in Burn

Pan 
TABLE A-1

THERMOCOUPLE LOCAT IONS AND

TEMPERATURE RECORDERS - EXPERIMENTAL - TEST F2

\begin{tabular}{|c|c|c|}
\hline TC NO. & Recorder \& Point & Location \\
\hline $\begin{array}{l}1 \\
2 \\
3 \\
4 \\
5 \\
6 \\
7 \\
8\end{array}$ & $\begin{array}{l}\text { C1 } \\
c 2 \\
c 3 \\
c 4 \\
D \\
06 \\
C 7 \\
c 7 \\
C 8 \\
c 9\end{array}$ & $\begin{array}{l}\text { (a) Under bottom course of brick } \\
\text { a). Between middle \& bottom course of brick } \\
\text { (a) Between top \& middle course of brick } \\
\text { (a) In sodium, on steel pan bottom } \\
\text { (a) In sodium, } 1.5 \text { in. above pan bottom } \\
\text { (a) In sodium } 3 \text { in. above pan bottom } \\
\text { (a) in sodium, } 4.5 \text { in. above pan bottom } \\
\text { In sodium, } 1.5 \text { in. above pan bottom } \\
\text { ( } 1 \text { in. from } \mathbf{E} \text { end) } \\
\text { In sodium, } 3 \text { in. above pan bottom }\end{array}$ \\
\hline $\begin{array}{l}10 \\
11 \\
12 \\
13 \\
14 \\
15 \\
16 \\
17 \\
18 \\
19\end{array}$ & $\begin{array}{l}\text { F1 } \\
\text { D (blue) } \\
\text { F2 } \\
\text { F3 } \\
\text { F4 } \\
\text { F5 } \\
\text { F6 } \\
\text { E1 } \\
\text { C10 } \\
\text { C5 }\end{array}$ & $\begin{array}{l}\text { (a) A ir over sodium, } 6 \mathrm{in} \text {. above pan bottom } \\
\text { (a) A i r over sodium, } 8 \text { in. above pan bottom } \\
\text { (a) A ir over sodium, } 13 \mathrm{in} \text {. above pan bottom } \\
\text { A i r over sodium, near bottom dummy pipe } \\
\text { (a) A ir over sodium, } 11 \mathrm{ft} \text { above mockup floor } \\
\text { (a) A ir over sodium, } 17 \mathrm{ft} \text { above mockup flo or } \\
\text { Air, } G \text { of } 10 \mathrm{ft} \text { x } 15 \mathrm{ft} \text { section } \\
\text { Air, } \mathrm{ft} \text { above mockup floor, } \mathrm{S} \text { end } \\
\text { Air, } 17 \mathrm{ft} \text { above mockup floor, } \mathrm{S} \text { end } \\
\text { Air, } 54 \mathrm{in} \text {. above mockup floor, } 3.5 \mathrm{ft} \text { ell, }\end{array}$ \\
\hline $\begin{array}{l}20 \\
21 \\
22 \\
23 \\
24 \\
25 \\
26 \\
27 \\
28 \\
29\end{array}$ & $\begin{array}{l}\text { E2 } \\
\text { E3 } \\
\text { C11 } \\
\text { E4 } \\
\text { C12 } \\
\text { E5 } \\
\text { E6 } \\
\text { E7 } \\
\text { G single } \\
\text { H single }\end{array}$ & $\begin{array}{l}\text { Air, } 17 \mathrm{ft} \text { above mockup floor, 3.5-ft. ell } \\
\text { Air, G of P-relief vent } \\
\text { Cell surface near burn pan } \\
\text { Outside insulation near burn pan } \\
\text { Cell surface, ceiling above burn pan } \\
\text { Outside insulation, ceiling above burn pan } \\
\text { Large Fire Room a ir inlet, Damper D9 } \\
\text { Large Fire Room exhaust air duct } \\
\text { Exhaust Fan a ir } \\
\text { Scrubber Outlet a ir }\end{array}$ \\
\hline
\end{tabular}

(a) $2 \mathrm{ft}$ from $E$ end on $q$ of pan. 
TABLE A-2

GAS SAMPLE POINT LOCATIONS

\begin{tabular}{|l|l|}
\hline $\begin{array}{l}\text { Sample } \\
\text { Pt. No. }\end{array}$ & Location \\
\hline 1 & $\begin{array}{l}\text { Inside burn pan, 12 in. from west end, 24 in. from } \\
\text { north end, 6 in. above sodium surface. }\end{array}$ \\
2 & $\begin{array}{l}16 \mathrm{ft} \text { above mockup floor, centered over the burn pan. } \\
\text { In the } 3.5-\mathrm{ft} \text { wide e11, 2 ft from west end, 2 f t abovi } \\
\text { floor. }\end{array}$ \\
\hline
\end{tabular}

TABLE A-3

AEROSOL SAMPLE POINT LOCATIONS

\begin{tabular}{|c|c|}
\hline Pt. No. & Location \\
\hline 1 & $\begin{array}{l}\text { Large Fire Room, } 9 \mathrm{ft} \text { above floor, } 6 \mathrm{in} \text {. from west } \\
\text { wall of Mockup, } 7 \mathrm{ft} \text { from north wall of Mockup. }\end{array}$ \\
\hline 2 & $\begin{array}{l}\text { Mockup, } 12 \mathrm{ft} \text { above floor, } 6 \text { in. from south wall, } \\
6 \text { in. from extreme west end of } 3.5 \mathrm{ft} \text { wide ell. }\end{array}$ \\
\hline 3 & Exhaust fan discharge. \\
\hline 4 & Between scrubber and HEPA filter bank. \\
\hline 5 & Downstream of HEPA filters. \\
\hline
\end{tabular}

. TABLE A-4

-

PRESSURE SENSOR LOCATIONS

\begin{tabular}{|l|l|}
\hline Pt. No. & Location \\
\hline$D P-1$ & $\begin{array}{l}\text { 14 ft above mockup floor, where } 3.5 \mathrm{f} \mathrm{t} \text { wide ell } \\
\text { joins } 10 \mathrm{ft} \times 15 \mathrm{ft} \text { section. }\end{array}$ \\
DP-2 & $\begin{array}{l}6 \text { in. above mockup floor, where } 3.5 \mathrm{ft} \text { wide ell } \\
\text { joins } 10 \mathrm{f} \mathrm{t} \times 15 \mathrm{ft} \text { section. }\end{array}$ \\
\hline
\end{tabular}




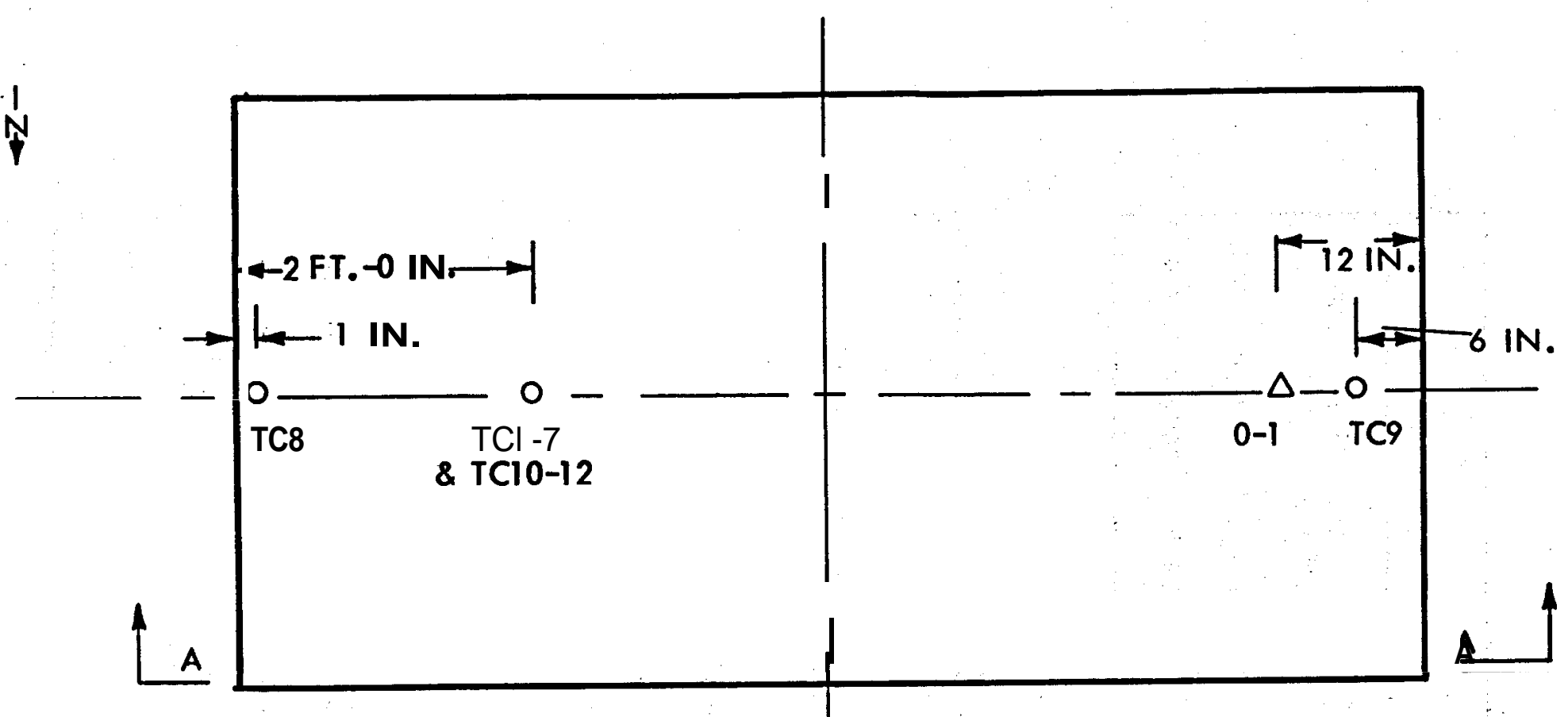

7



FIGURE A-1. Thermocouple Locations In Burn Pan-Test F2. 
APPENDIX B

NARRATME OF KEY TEST EVENTS AND OBSERVATIONS

- Time After

Sodium Spill

$(-) 10 \mathrm{~min}$

0

$6 \sec$

$26.5 \mathrm{sec}$

$30 \mathrm{sec}$

$2 \min$.

$5 \min$

$75 \min$

$15.05 \min$
Event.

Pressurize batch tank to $9.5 \mathrm{psig}$, N temp $1100^{\circ} \mathrm{F}$. Closed switch to open 3-in. spill valve.

First evidence of sodium reaching burn pan seen by TV camera. First evidence of pressure increase. Incandescent particles reflected from pan bottom in

5 sec after spill,

Maximum pressure of 1.4 in. $\mathrm{H}_{2} \mathrm{O}$ attained. View of burn pan obscured by smoke. Entire spill nearly identical'to test Fl visually.

Batch tank at zero pressure. First sight of smoke emitted from relief vent and vacuum breaker. Smoke consists of very small particles.

Temp of th pool near surface $=890^{\circ} \mathrm{F}$; on pan bottom $=785^{\circ} \mathrm{F}$; average of $6 \mathrm{TC}^{\prime} \mathrm{s}=845^{\circ} \mathrm{F}, \mathrm{O}_{2}$ concentration 19.8\%. DP 0.1 inches $\mathrm{H}_{2} \mathrm{O}$. Average cell air temperature $148^{\circ} \mathrm{F}$.

$\mathrm{N}$ pool $905^{\circ} \mathrm{F}$ average, $\mathrm{DP}=0.01$ in. $\mathrm{H}_{2} \mathrm{O}, \mathrm{O}_{2}$ concentration $18.6 \%$. Visibility in fire room is improving. Better visibility near floor than higher up. Average cell air temperature $169^{\circ} \mathrm{F}$.

$\mathrm{N}$ pool $1025^{\circ} \mathrm{F}$ average; cell air $238^{\circ} \mathrm{F}$ average; $\mathrm{O}_{2}$ concentration $14.0 \%$; DP $=0.03$ in. $\mathrm{H}_{2} \mathrm{O}$ at $14 \mathrm{ft}$ elevation, $(-) 0.01$ at 6 in. elevation. Maximum smoke concentration in cell at $13 \mathrm{~g} / \mathrm{m}^{3}$.

Start $\mathrm{N}_{2}$ flood (flow rate 60 SCFM). Smoke emission from mockup immediately increased, $D P=0.31$ in. $\mathrm{H}_{2} \mathrm{O}$, 
APPENDIX B, (cont.)

Time After

$\underline{\text { Sodium Spill }}$

25 min

50 min

$120 \min$

$140 \min$

$220 \min$

$236 \min$

$420 \min$

$460 \min$

$540 \min$

$750 \min$

$870 \min$

1080 min

\section{Event}

$\mathrm{Na}$ pool reached maximum temperature of $1055^{\circ} \mathrm{F}$ average. Cell air $276^{\circ} \mathrm{F} ; 09=0.35$ in. $\mathrm{H}_{2} \mathrm{O}, \mathrm{O}_{2}$ concentration $7.8 \%$. Cell air reached maximum temperature of $296^{\circ} \mathrm{F}$; Na pool $885^{\circ} \mathrm{F}$ average; $O P=0.54$ in. $\mathrm{H}_{2} \mathrm{O} ; \mathrm{O}_{2}$ concentration $1.67 \%$. Maximum temperature of $395^{\circ} \mathrm{F}$ reached at bottom of top course of firebrick. N pool $575^{\circ} \mathrm{F}$ average; $\mathrm{O}_{2}$ concentration $0.13 \%$; $D P=0.70$ in. $\mathrm{H}_{2} \mathrm{O}$.

Visibility in fire room very clear. Oxide is plugging vacuum breaker and occassionally falling in lumps to the floor. Visibility inside mockup improving.

Started to terminate $\mathrm{N}_{2}$ flood. N pool $370^{\circ} \mathrm{F}$ average; cell air $191^{\circ} \mathrm{F}$ average; $D P=0.60$ in. $H_{2} \mathrm{O} ; \mathrm{O}_{2}$ concentration $0.02 \%$. View of burn pan fairly clear.

$\mathrm{N}_{2}$ flood gas off after a series of flowrate reductions to measure leak rate.

Visibility within mockup very good. N pool $264^{\circ} \mathrm{F}$; cell air $157^{\circ} \mathrm{F} ; \mathrm{O}_{2}$ concentration $2.2 \% ; D P=0$.

Visibility within mockup getting worse. Smoke beginning to exit through vacuum breaker vent. N pool $255^{\circ} \mathrm{F} ; \mathrm{O}_{2}$ concentration $2.6 \%$.

Visibility zero within mockup. N pool continuing to cool to $234^{\circ} \mathrm{F} ; \mathrm{O}_{2}$ concentration is decreasing at $2.5 \%$. Visibility within mockup improving. N pool $212^{\circ} \mathrm{F}$; cell air $138^{\circ} \mathrm{F} ; \mathrm{O}_{2}$ concentration $1.97 \%$.

Visibility clear within mockup. Nh pool $210^{\circ} \mathrm{F} ; \mathrm{O}_{2}$ concentration $2.45 \%$.

Perform leak test on mockup; N pool $170^{\circ} \mathrm{F}$. 
Time After

Sodium Sp 111

1250 min

$2580 \min$

$2660 \min$

$2710 \min$

\section{Event}

Start $\mathrm{N}_{2}$ flood at 20 SCHM to prevent further sodium change prior to sampling. Na pool $152^{\circ} \mathrm{F}$; cell air $109^{\circ} \mathrm{F} ; \mathrm{O}_{2}$ concentration $3.65 \%$.

Start air flow through mockup at 21000 CFM. Na pool temperature $85^{\circ} \mathrm{F}$.

Remove door of mockup and take samples of sodium residue.

All samples taken. 


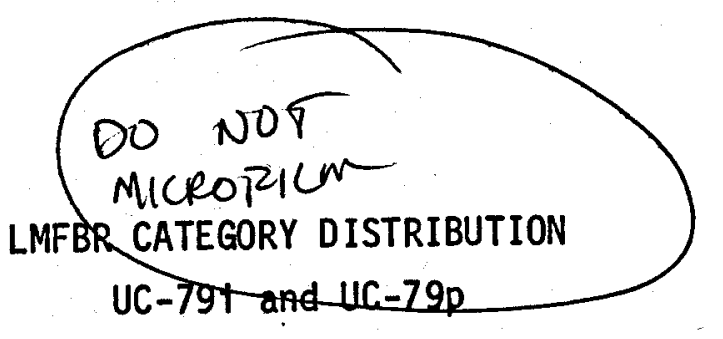

UC-79 (206)

UC-79i (20)

$U C-79 p$

J. R. Bell

C. S. Carlisle

D. A. Davis

A. Fremling

P. G. Holstead

D. W. Mazur

R. M. Poteat

F. R. Standerfer

A. S. Waterhouse

RDPO-RL

R. L. Ferguson

HEDL

J. M. Atwood

J. L. Ballif

A. G. Blasewitz

R. K. Brown

R. 0. Budd

C. J. Boasso

J. J. Cadwel1

W. H. Caplinger

G. D. Carpenter

H. o. Charnock

E. C. Diedrich

E. A. Evans

D. Gray

J. P. Hale

T. 0. Harves

j. A. Hassberger' (2)

H. D. Haberman

R. K. Hilliard

D. I. Hulbert

E. M. Johnston

W. L. Karlin

W. C. Kinsel

R. F. Keough

F. J. Leitz

C. E. Linderoth

J. J. Mahoney

J. D. MeCormack

P. E. McPherson

L. D. Muhlestein (2)

C. A. Munro

B. H. Noordhoff

R. E. Peterson

A. J. Powell

G. J. Rogers

M. 0. Rankin

P. R. Shire

D. E. Simpson

C. T. Schaedel

R. J. Slember

L. R. Sweet in

A. Squire

W. E. Taylor

W. L. Thorne

K. G. Toyoda

A. L. Trego

S. A. Weber

J. H. Westsik

W. R. Wykoff

J. M. Yatabe

K. L. Young

W. H. Yunker

Document Control , (10)

(2) Technical Publications (2)

Dist-1 